\title{
Planning for climate change impacts on hydropower in the Far North
}

\author{
Jessica E. Cherry ${ }^{1}$, Corrie Knapp ${ }^{2}$, Sarah Trainor ${ }^{3}$, Andrea J. Ray ${ }^{4}$, Molly Tedesche ${ }^{5}$, and Susan Walker ${ }^{6}$ \\ ${ }^{1}$ International Arctic Research Center and Institute of Northern Engineering, University of Alaska Fairbanks, \\ Fairbanks, Alaska 99775, USA \\ ${ }^{2}$ Department of Environment \& Sustainability, Western State Colorado University, Gunnison, Colorado 81231, USA \\ ${ }^{3}$ Alaska Center for Climate Assessment and Policy, University of Alaska Fairbanks, Fairbanks, Alaska 99775, USA \\ ${ }^{4}$ Earth System Research Laboratory-Physical Sciences Division, National Oceanographic and Atmospheric Administration, \\ Boulder, Colorado 80305, USA \\ ${ }^{5}$ International Arctic Research Center, University of Alaska Fairbanks, Fairbanks, Alaska 99775, USA \\ ${ }^{6}$ National Oceanographic and Atmospheric Administration-National Marine Fisheries Service, Juneau, Alaska 99801, USA
}

Correspondence to: Jessica E. Cherry (jessica.cherry@alaska.edu)

Received: 11 April 2016 - Published in Hydrol. Earth Syst. Sci. Discuss.: 24 May 2016

Revised: 4 November 2016 - Accepted: 27 November 2016 - Published: 9 January 2017

\begin{abstract}
Unlike much of the contiguous United States, new hydropower development continues in the Far North, where climate models project precipitation will likely increase over the next century. Regional complexities in the Arctic and subArctic, such as glacier recession and permafrost thaw, however, introduce uncertainties about the hydrologic responses to climate change that impact water resource management. This work reviews hydroclimate changes in the Far North and their impacts on hydropower; it provides a template for application of current techniques for prediction and estimating uncertainty, and it describes best practices for integrating science into management and decision-making. The growing number of studies on hydrologic impacts suggests that information resulting from climate change science has matured enough that it can and should be integrated into hydropower scoping, design, and management. Continuing to ignore the best available information in lieu of status quo planning is likely to prove costly to society in the long term.
\end{abstract}

\section{Introduction}

The generation of conventional hydroelectric power in the contiguous United States has declined over the past several decades, while use of other renewables has grown considerably (Fig. 1). Hydropower generation has declined due to the impacts of precipitation variability and drought, enforcement of in-stream flow regulations, and a drop in capacity when dams are removed (EIA, 2015; Malewitz, 2014). Few new facilities have been built in the United States because of the impacts of dams on fish habitat, challenges of property and water rights, the high cost of dam construction, and simply because easy-to-develop projects were already built in the early years of the national reclamation movement (Gallucci, 2014; Malewitz, 2014). In contrast, both hydropower generation and capacity in the Far North - Alaska, Canada, and much of Scandinavia - are actively growing (Figs. 2 and 3). In Alaska, in particular, several new projects are being proposed, including a massive 750-foot high, 600 MW Dam on the Susitna River in the south-central part of the state (AEA, 2016; REAP, 2016). This project was still in the pre-licensing phase at the time of writing.

While the Far North (defined here as the Arctic and subArctic) may have considerable water resources (e.g., AEDI, 2016; Conner and Francfort, 1997), questions about climate change impacts on existing and proposed hydropower projects relate to unique environmental complexities that require consideration across the boreal, sub-Arctic, and Arctic regions. How will climate change impact glacier runoff? How does thawing of permafrost (soils that used to remain frozen throughout the year) impact partitioning of runoff into surface and subsurface waters? Where and when will 


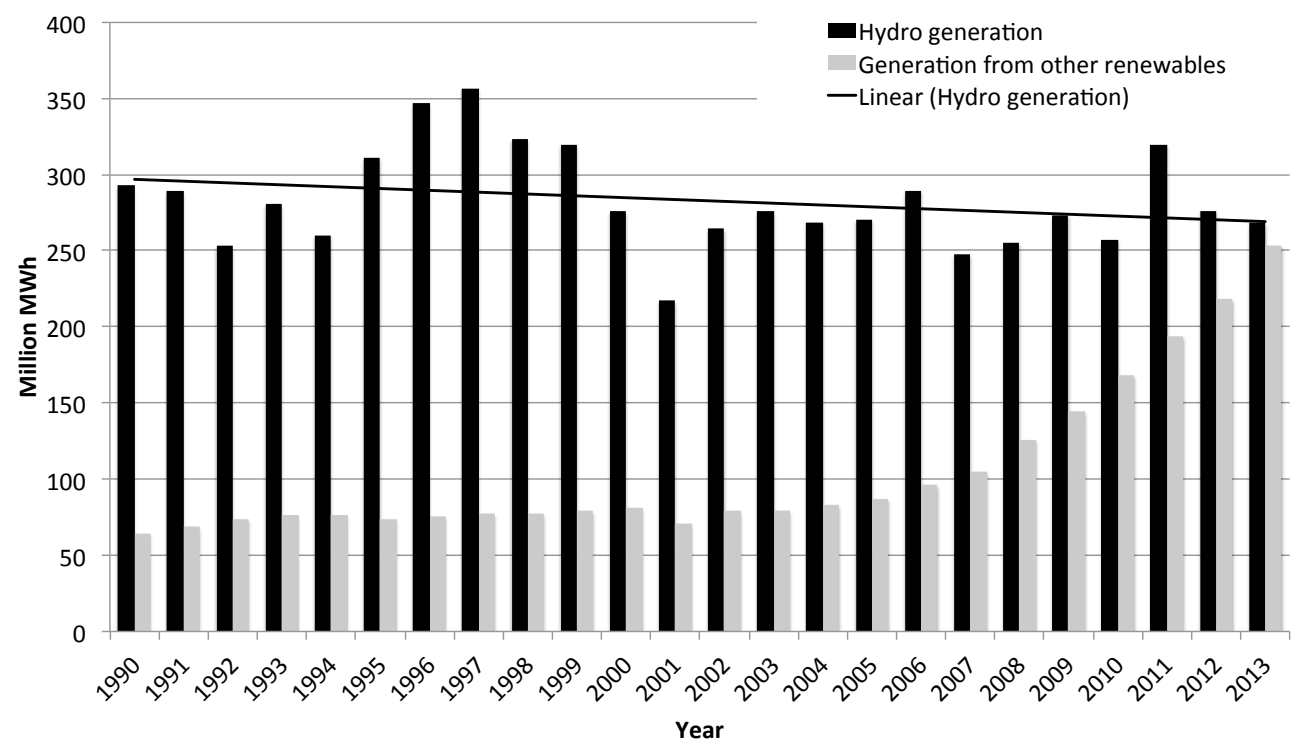

Figure 1. Trends in hydropower production and other renewables in the United States. Data are from http://www.eia.gov/electricity/annual/.

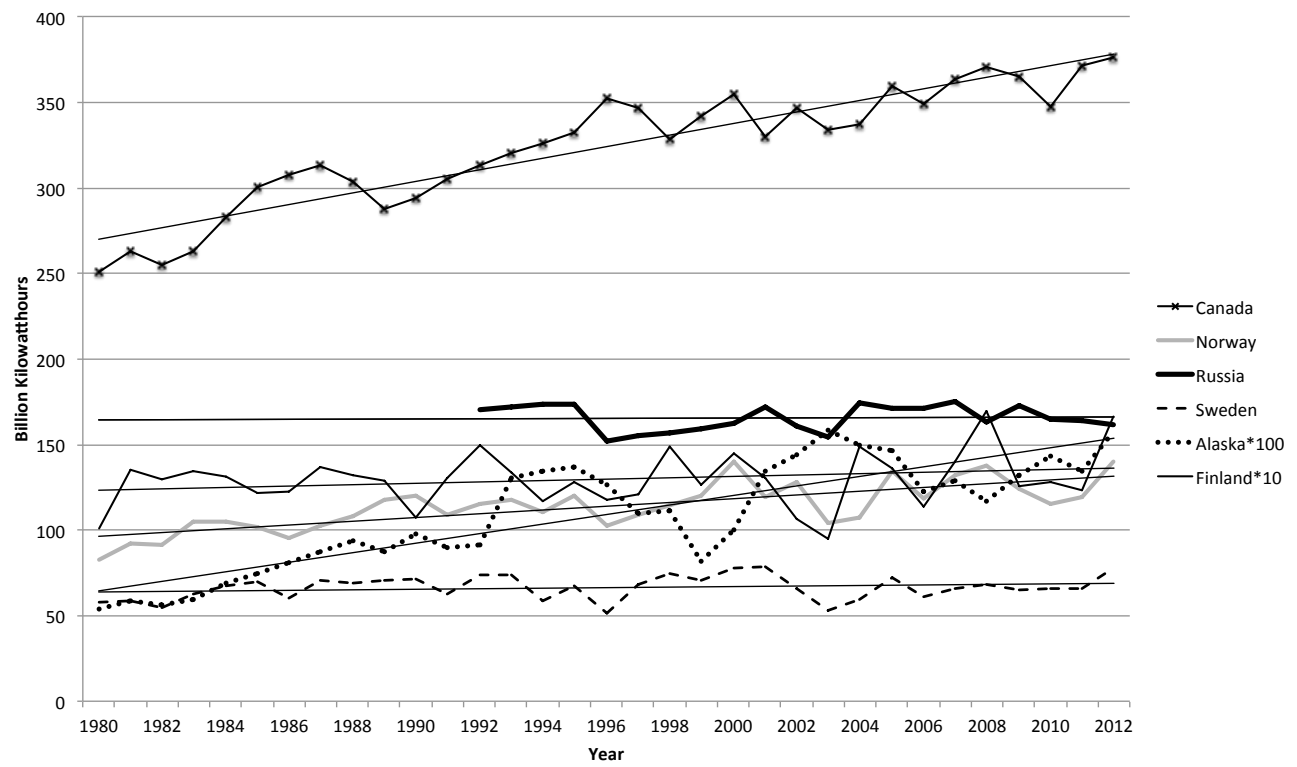

Figure 2. Trends in hydropower generation in selected northern regions, 1980-2012. Data are from the Energy Information Administration and the Alaska Energy Data Gateway. Generation statistics in Alaska and Finland have been multiplied by factors that make them easier to visualize on the same graph as the other data.

the phase of precipitation change from snow to rain and how will total precipitation volumes and timing of storage change? How do changes in air and water temperatures impact the timing of snowmelt, river ice cover, and runoff? Do changes in glaciers and ground ice impact river sediment loads and subsequently fish habitat and potential or existing hydropower infrastructure? While these climaterelated questions also apply to alpine hydropower areas in the contiguous United States, they are major concerns for hydropower in the Far North and have received little atten- tion. Figure 4 shows that the percent of hydropower capacity used in the Far North has actually decreased in several countries, suggesting either the impacts of a changing climate, a misalignment of infrastructure and resources, or both. It may also reflect an increasing number of in-stream flow regulations and other actions responding to concerns about the impacts of hydropower on ecosystems and the environment. Because of the ongoing energy development throughout the Far North, there is an urgent need to understand the interaction of changing climate and hydropower. 


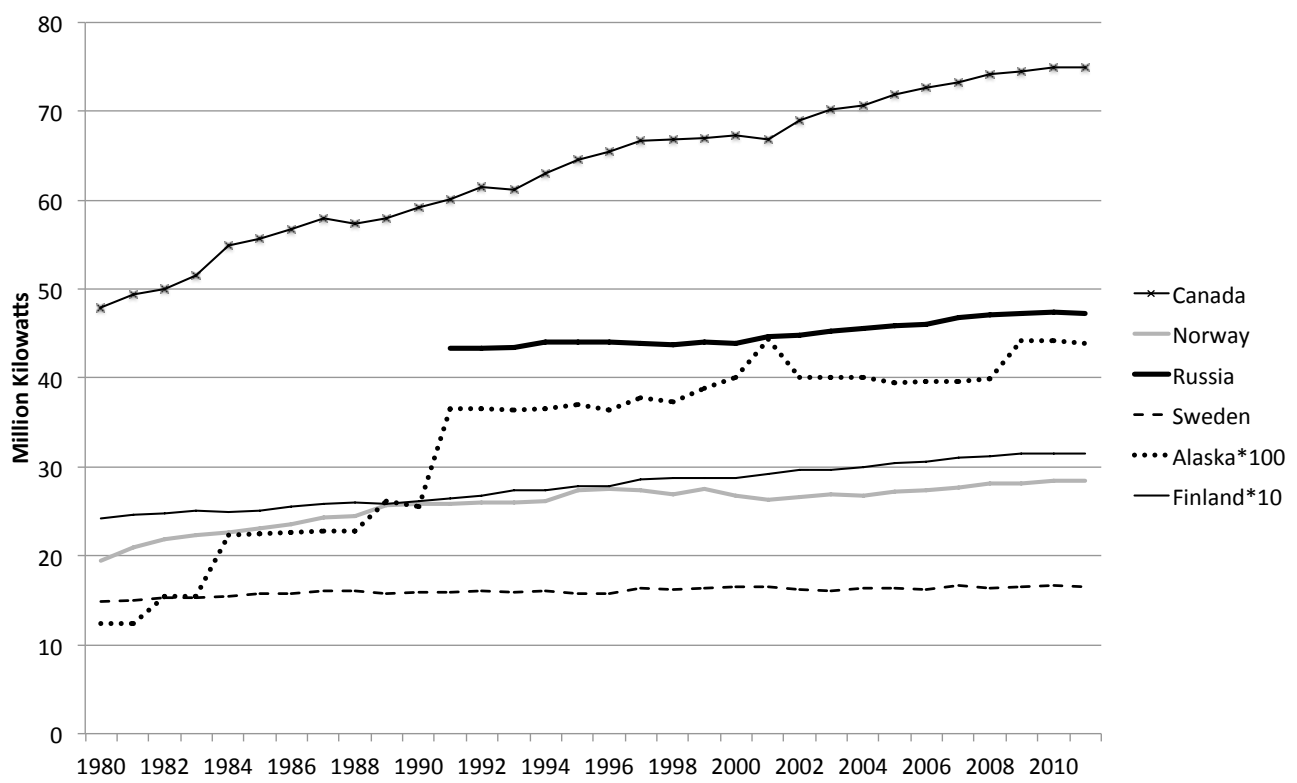

Figure 3. Trends in hydropower capacity in selected northern regions, 1980-2012. Data are from the Energy Information Administration and the Alaska Energy Data Gateway. Capacity statistics in Alaska and Finland have been multiplied by factors that make them easier to visualize on the same graph as the other data.

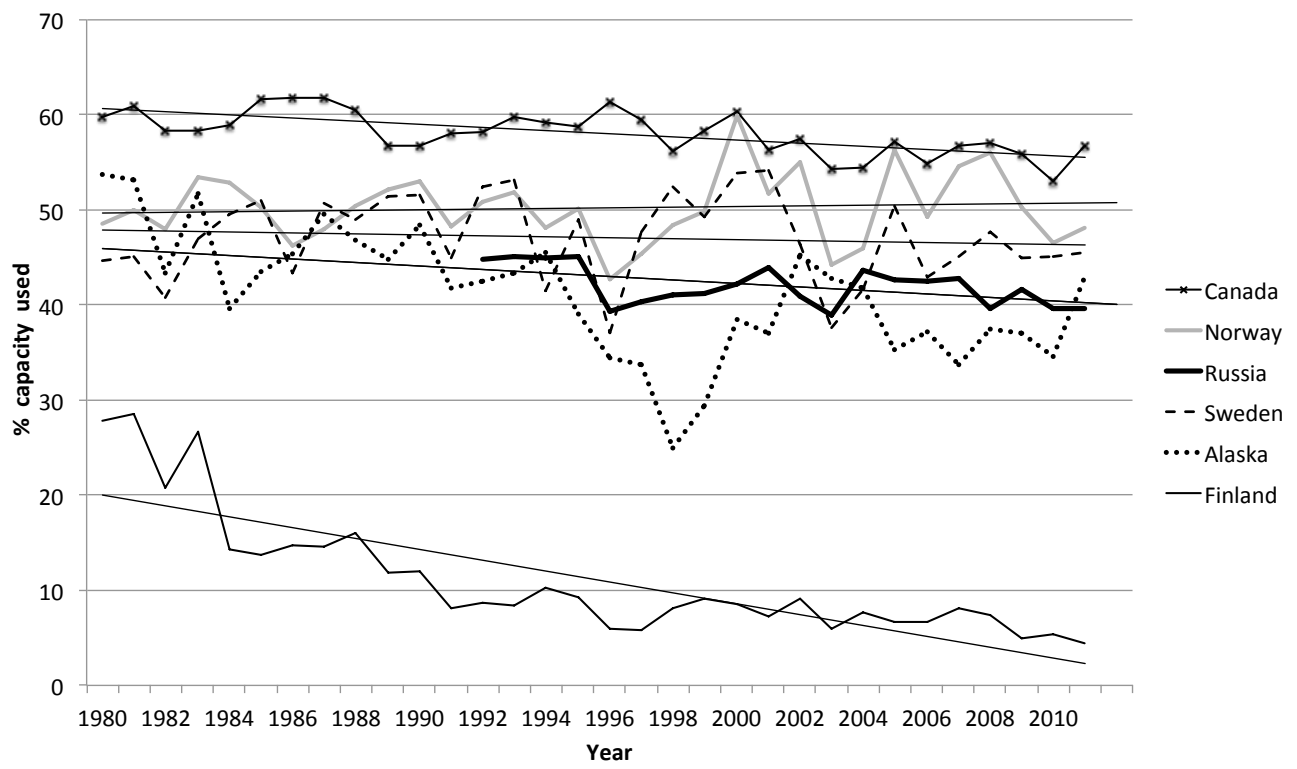

Figure 4. Percent capacity of hydropower used in selected northern regions, 1980-2012. Data are from the Energy Information Administration and the Alaska Energy Data Gateway.

There is widespread consensus that climate change will impact water resources globally and regionally (Georgakakos et al., 2014; Jiménez Cisneros et al., 2014; Mukheibir, 2013; Beniston, 2012; Viviroli et al., 2011; Fenner, 2009; Vicuna et al., 2008; Barnett et al., 2005; Payne et al., 2004). The volume and timing of runoff in many northern locations are already changing (e.g., Wolken et al., 2015; Dahlke et al., 2012; Jones and Rinehart, 2010; Wilson et al.,
2010), as well as the amount and form of precipitation (Walsh et al., 2014; Callaghan et al., 2011a, b). Increasing precipitation patterns are expected to favor northern latitudes (Fig. 5), increasing the water available for hydropower production (Jiménez Cisneros et al., 2014; Hamududu and Killingtveit, 2012). However, the impacts of climate change will be further complicated by several factors including glacial wasting, permafrost thaw, and erosion (Bliss et al., 2014; Quinton et 
al., 2011; Wada et al., 2011). These characteristics of northern systems may impact the long-term risk associated with hydropower projects through changes to in-stream flow, increased sedimentation, and vulnerability to hazards such as glacial burst flooding and seismic activity related to changes in water/glacier mass loading.

Because of the long design life of hydropower infrastructure (100 years or longer), it is important to consider climate change and impacts unique to far northern regions in both the project planning and operations phases (Viers, 2011; Markoff and Cullen, 2008). Uncertainties related to these climate impacts may affect the viability of a proposed project. The intent of this article is to discuss the state of the relevant climate science with a focus on far northern regions, to describe methods for predicting water supply and estimating uncertainty in northern hydroclimatology, and also to discuss strategies for integration of climate change science into hydropower planning, management, and barriers to this process. Finally, we propose best practices for the use of climate change information in planning new projects and operating existing facilities, to incorporate the range of possible future scenario represented by uncertainty.

\section{Climate change impacts on hydropower}

\subsection{Scope and methods of study}

The scope of this article is to describe the observed and projected climate impacts that would affect proposed and existing projects and how this information relates to planning and management. In the subsections below, we will discuss general impacts of climate change and variability on hydropower systems followed by a focus on far northern regions. We acknowledge that hydropower projects may be an opportunity to mitigate global climate change, and in some regions may represent the best possible power source for minimizing the carbon footprint, environmental pollution, and feedbacks to the global climate. Interest in the sustainability of hydropower relative to other sources of energy is contributing to its growth trend in regions outside of the contiguous United States and, as we will argue, hydropower infrastructure is vulnerable to climate change and variability. This growth in hydropower development makes it critical to study the linkages between hydrologic change and project risk (Harrison et al., 2003).

Likewise, there are significant effects that hydropower projects have on their environments, which are arguments against their sustainability. These include destruction of fish habitat and damage to the ecosystems that depend on them. They include flooding of land that previously had other ecosystem functions and may have contained private property or cultural resources. Furthermore, the greenhouse gas methane is produced from anoxic decomposition of submerged vegetation in newly flooded areas behind dams (Scherer and Pfister, 2016). There are also changes to local microclimates and enhanced evaporation caused by reservoirs in conventional, large hydropower projects. These feedbacks from hydropower facilities onto the environment, again, are not the focus of this article. In the subsections below, we will discuss general impacts of climate change and variability on hydropower systems followed by a focus on far northern regions.

Literature was analyzed using an inductive approach; an incomplete set of prior hydrologic studies have been performed in many regions, let alone, the Far North, but specific examples were used to construct more generalized best practices. Google's default search engine, as well as Google Scholar, and ISI's Web of Science were scanned with the following terms: hydrology, hydrologic modeling, water resources, glaciers, groundwater, water and climate change, hydropower, hydroelectric power, with and without regional qualifiers such as Canada, Russia, Scandinavia (and specific countries therein), and Alaska. Large publications in the field, such as those by the Intergovernmental Panel on Climate Change author teams and the National Climate Assessment author teams, were searched for relevant material. Resulting articles from peer-reviewed and gray literature were cataloged in a database. Analysis focused on peer-reviewed and government-authored reports, and viewed trade publications (for example from the hydropower industry) as potentially biased.

\subsection{Climate change impacts on hydropower supply and demand}

The water supply for generating hydropower is derived from precipitation (rain and snow), surface water, groundwater that makes its way to the surface, and glacial melt in northern and alpine areas. In much of the tropical and temperate regions, water supply is a balance of precipitation, evapotranspiration (ET), and storage. Globally, trends in precipitation have been difficult to detect, but the IPCC AR5 described the increase in historical precipitation from 60 to $90^{\circ} \mathrm{N}$ as likely ${ }^{1}$. The problem of trend detection in the Far North is more challenging than in warm climates because solid precipitation is particularly difficult to measure and much of the year precipitation falls as snow. Measurement errors, siting biases, poor spatial coverage, and network heterogeneity over time all reduce the confidence in trends of snowfall (Cherry et al., 2005a, 2007). However, for three out of four global data sets, the trend for precipitation between 60 and $90^{\circ} \mathrm{N}$ was shown by the IPCC AR5 authors to have increased for the period 1951-2008, and more so than in any other region.

McAfee et al. $(2013,2014)$ published two studies that focused on estimating precipitation trends in Alaska. Using sta-

\footnotetext{
${ }^{1}$ The IPCC defines likely as having a $66-100 \%$ probability (Mastrandrea et al., 2010).
} 


\section{Projected Change in Average Annual Precipitation}

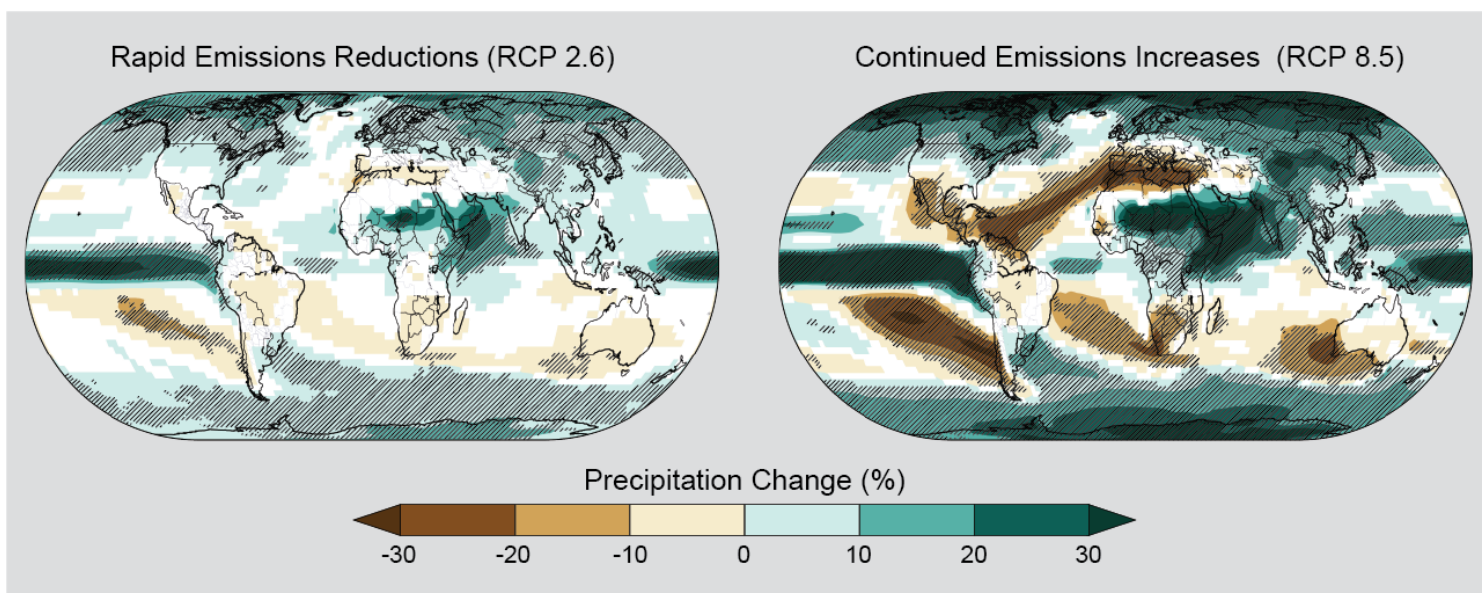

Figure 5. Projected change in average annual precipitation, reproduced from the 3rd National Climate Assessment (Walsh et al., 2014). Gray hatching represents statistically significant changes that are also consistent across multiple models.

tion data and gridded analyses, these studies showed that inhomogeneity in the observational networks makes trend detection here nearly impossible at this time. Those authors found that virtually no significant trends in precipitation could be derived directly from station data. According to McAfee et al. (2013, 2014), the gridded Global Precipitation Climatology Center (GPCC) data set appears most reliable, shows an increase in annual precipitation in Arctic Alaska, and a slight decrease in annual precipitation in the southern half of the state between 1980 and 2008, though few regions show any statistical significance. These authors also reviewed more than a dozen other studies on precipitation trend analyses in Alaska and showed that results are entirely dependent on the sites used and the period of time selected. Rawlins et al. (2010) did a similar calculation for precipitation trends across the pan-Arctic using observations, climate models, and reanalysis data, and found increasing precipitation trends from 1950 to 2008 and 1980 to 2008 for all but one data set.

Of these precipitation trend analyses, few have focused on long-term snowfall in particular. In Canada, however, a study found that snowfall increased in the northern part of the country, but actually decreased in the southern part (Mekis and Vincent, 2011). In the future, this will most likely be the pattern from first principles of the physics and thermodynamics of a rotating planet; because of the warming atmosphere and enhanced transport of moisture from lower latitudes, the northern-most regions of the Far North will likely receive more snowfall and the southern portion of the Far North will likely receive more rain in a changing climate (Serreze and Barry, 2014). These results are also seen in modeling studies (e.g., Peacock, 2012). For hydropower in the Far North, this is likely to mean more supply available overall. In the southern-most parts of this region, more precipitation will arrive in liquid form and be available earlier in the season for hydropower generation, rather than stored in the snowpack until spring melt. In the Far North, ET is a relatively small portion of the hydrologic budget and precipitation dominates (Kane et al., 1990), though ET will increase as the growing season continues to lengthen as it has in recent decades (Genet et al., 2013; Olchev and Novenko, 2011; Zeng et al., 2011). Other aspects of the supply side, which include groundwater storage and glacier storage, will be addressed in the next section on regional complexity.

Air temperature increases in the Far North are a robust signal and the IPCC AR5 report denotes high confidence ${ }^{2}$ in these trends. In the Arctic, temperature has had the biggest increasing trend in autumn (September-November) over the past 3 decades (Cohen et al., 2012a; Alaska Climate Research Center, 2016). This increase in autumn air temperatures may delay the establishment of the snowpack and reduce availability of water in reservoirs during the following spring. An increase in the number of rain on snow events, driven by warming, can also lead to more available water in northern reservoirs during the cold season. Air temperature trends also have a major impact on hydropower demand, especially in areas where home and commercial heating is supplied by this electricity. Many places in the Far North have warmed considerably during the winter season, but in other places, recent modeling work has shown that colder winters, particularly in northern Europe over the last 3 decades, are also consistent with climate change (Cohen et al., 2012b). Seasonal asymmetries in warming trends (Cohen et al., 2012a) certainly have the ability to change the timing and magnitude of the demand for hydropower.

\footnotetext{
${ }^{2}$ The IPCC defines high confidence as having both high agreement and robust evidence (Mastrandrea et al., 2010).
} 
The co-variability of temperature and precipitation anomalies is important because it can affect the impact or hardship experienced by hydropower users. For example, if there is a shortage of precipitation, but a warm air temperature anomaly, the impact of the water shortage might be much less than if there were a wintertime cold anomaly. Cherry et al. (2005b) showed that the co-variability of Scandinavian precipitation and temperature driven by the North Atlantic Oscillation (NAO) trends tended to cause significant impacts because cold winters occurred during dry anomalies and the hydropower supply was short when demand was high. Modes of climate variability such as El Niño-Southern Oscillation (ENSO) and the NAO influence temperature-precipitation co-variability as well as seasonal asymmetries in long-term climate trends.

For both precipitation and temperature, there is some debate whether non-stationarity (change in the long-term mean) persists over the period of instrumental record (Rhines and Huybers, 2013; Hansen et al., 2012) and this has obvious implications for reservoir construction and management (Brekke et al., 2009). However, changes in climate variability, including location, timing, magnitude, and extreme events also have implications for reservoir construction (i.e., design capacity) and management (i.e., timing of generation, flood control, and water spilling).

There are relatively few publications about changes in extreme events for the Far North, probably due to the same issues with data quality that affect our confidence in basic trends. However, atmospheric circulation has shifted poleward since the 1970s and this has pushed the storm tracks northward and contracted the polar vortex (Hartmann et al., 2013), providing a physical basis for changes in extremes at a given place. An assessment by Melillo et al. (2014) shows a significant decrease in cold days and cold nights and a significant increase in warm days and warm nights, observed for the high latitudes since 1950. Bennett and Walsh (2015) looked at historical and projected changes in extreme temperature and precipitation events in Alaska and found significantly fewer extreme minimum temperatures in the cold seasons and significantly more 5-day duration precipitation events. The impact of these changes on hydropower is that designers of new projects need to consider the possibility of heavier precipitation events and more surface runoff during fall, winter, and early spring due to warmer nights. This could lead to the spillage of excess water without generation, if the reservoirs are capacity limited and already full during those times of the year.

Extreme temperature and precipitation events may also link to sedimentation in reservoirs because, on principle, more force moves more sediment (Toniolo and Schultz, 2005). Other impacts of climate change on hydropower supply and demand include factors that affect runoff partitioning into surface water and groundwater. These could be changes in the mean or extreme events. These factors include climatedriven changes in vegetation and soil moisture. Studies of these trends, however, would depend on long-term, consistent, accurate, and co-located measurements of river discharge, vegetation, precipitation, and soil moisture, which are hard to find in the Far North.

\subsection{Climate change complexity in the Far North}

There are also complexities of changes in the Arctic, subArctic, and alpine areas that are unique to the Far North. These include permafrost, sedimentation from thaw slumps, and glaciers. Ice rich permafrost acts as an aquatard, blocking passage of water through soil and limiting subsurface connectivity in groundwater (Carey et al., 2013) ${ }^{3}$. As it thaws under a warming climate, subsurface storage and connectivity is anticipated to increase, but there is uncertainty about whether this will lead to more runoff and water availability for hydropower production and other hydroclimate impacts. For example, in areas of currently continuous permafrost, permafrost could thaw disconnected areas and pull water down to the subsurface, but these could be in isolated voids and not part of a groundwater system that contributes to runoff. In areas of discontinuous permafrost, additional thawing is more likely to lead to changes in river discharge since the subsurface is more likely connected to runoff pathways. If surface waters infiltrate into the subsurface and soil is allowed to dry under either of these scenarios, there may be less moisture contributed to the regional atmosphere from the land surface, and less summer precipitation, in turn.

Permafrost degradation in ice rich soil can also lead to thermokarst formation, in which thermal and water-driven erosion releases a significant volume of sediment into a waterway, typically during a catastrophic collapse over a period of a few weeks to a couple of years. These types of sedimentation events can reduce reservoir capacity and increase wear and tear on turbines in projects built adjacent to permafrost (Toniolo and Schultz, 2005; Gurnell, 1995). Newly built reservoirs will also impact permafrost distributions as the reservoirs fill and water has the potential to thaw additional soil in the newly formed or enlarged lake.

Glacier dynamics is an additional complexity in northern climates. Glacial retreat is a widespread phenomenon throughout the Far North and many existing and proposed hydropower projects depend on river discharge from catchments with glaciers in the headwaters. As glaciers melt, they generate increasing annual discharge until this runoff reaches a peak, and declines thereafter (Fig. 6). Several researchers have suggested that most non-coastal glaciers are already past peak melt and that discharge from glacial sources is already declining (O'Neel et al., 2014; Radić and Hock, 2014; Arendt et al., 2002, 2009). Thus, the state and trajectory of glacial runoff is an important factor in designing hydropower

\footnotetext{
${ }^{3}$ Permafrost that is not ice rich may simply be frozen gravel or other material that still allows liquid to pass through to the deeper subsurface. Ice rich permafrost tends to be associated with big ice wedges and lenses, which are effective aquatards.
} 


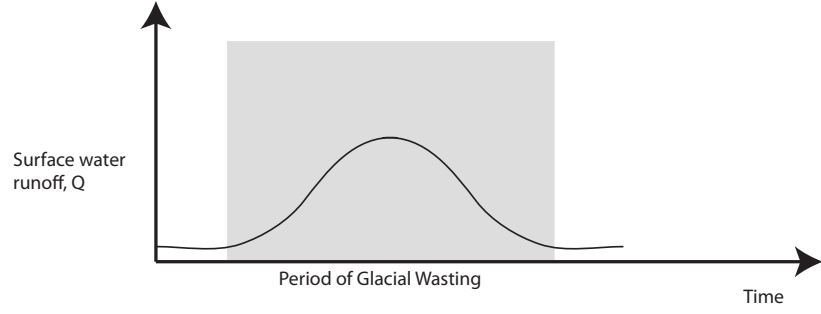

Figure 6. Conceptual graph of surface water runoff as a function of time when glaciers are wasting. Modified from Jansson et al. (2003).

projects and accurately estimating future reservoir inflow. The rates of melting glacial ice can also impact soil moisture and runoff partitioning: fast melt will lead to more saturated soil and surface runoff while slow melt is more likely to contribute to groundwater, so long as there is some discontinuity of the permafrost in the watershed. Finally, like permafrost degradation, retreating glaciers can leave behind large amounts of mobile sediment (Gurnell, 1995; Harrison et al., 1983), which can be transported into hydropower infrastructure and reduce the lifespan of turbines and reservoirs.

Climate change is also increasing the potential for glacial hazards. The melting of permafrost, along with glacial wastage, can lead to glacial lake outburst events (Bolch et al., 2011), which have increased in number and magnitude in recent years (Sorg et al., 2012; Narama et al., 2010; Horstmann, 2004; Agrawala et al., 2003). These glacial hazards may be a threat to hydropower infrastructure (Richardson and Reynolds, 2000). In addition, glacial wastage is likely to increase the potential for flooding (Veijalainen et al., 2010; Kutuzov and Shahgedanova, 2009). While dams can be damaged by flooding, they can also be a way to mitigate flood risk by controlling water flow (World Bank, 2009).

Climate change is likely influencing the thickness of river and lake ice, as well as the timing of breakup, which has a significant impact on reservoir inflows. Numerous ice-related changes can be a challenge for hydropower operation, including a shift in patterns or frequency of ice blockage and jams (Gebre et al., 2013). Hydropower operators need to take into account these changing ice conditions, regardless of whether a project is run-of-river or has a reservoir (Prowse et al., 2011). Change in the duration and extent of ice cover is likely (Timalsina et al., 2013; Andrishak and Hicks, 2008). The later freeze up of lakes and rivers can lead to increased development of ice dam flooding or damage to infrastructure in the autumn (Molarius et al., 2010). Climate change has been shown to increase the frequency of spring ice jam floods in some regions (Bergstrom et al., 2001) while mid-winter ice on snow events and atypical mid-winter thaws can also result in mid-winter ice jams and associated flooding (Prowse and Beltaos, 2002).
Polar climate is changing more rapidly than that of lower latitudes, a phenomenon known as polar amplification (Serreze and Barry, 2014). The movements of pressure centers and the polar vortex, as well as changing sea ice cover, are impacting regional hydroclimatology. Researchers have described several mechanisms for polar amplification in the climate system. One of these mechanisms is the lowering of polar surface albedo as light-colored ice and snowmelt, exposing dark ocean and land surfaces, which in turn absorb more heat from solar radiation. Other reasons for polar amplification relate to the mass gradient in the atmosphere, from the Equator to the poles, driven by atmospheric temperature and pressure. Heat and moisture tend to flow along this gradient, poleward. Projected rates of hydroclimate change in globalor low-latitude studies may underestimate the true rates of change for high latitudes in the future because of the imperfect representation of these processes in models (Clark et al., 2015; Christensen et al., 2013).

While scientists anticipate climate change will drive warmer, moister air poleward, air parcels are rarely transported directly meridionally (Francis and Vavrus, 2015). Instead, they are subject to Coriolis deflection and controlled by persistent lows and highs in the atmosphere. In the Far North, the Aleutian low, Icelandic low, Siberian high, and polar vortex are persistent patterns of circulation that help direct atmospheric fronts and the movement of weather patterns that ultimately add up to climate. These persistent, co-varying patterns of circulation, also known as oceanatmosphere oscillations (such as the Pacific Decadal Oscillation, NAO, or ENSO) are modes of climate variability. While quantifying this variability with an oscillation index or another statistical tool can be useful for analyzing impacts, there are limits to how well the indices describe or predict the dynamics of persistent circulation patterns that actually determine local weather. In other words, while climate change theory and models predict a warmer, wetter north, that does not mean that more precipitation will necessarily arrive at a particular locality; it may be further to the east or west because of persistent circulation patterns.

Finally, other complexities in the Far North relate to social impacts of hydropower development in a changing climate. While the northern-most regions of the Earth are relatively sparsely populated, many indigenous and other rural people not only live in communities that depend heavily on subsistence and commercial hunting and fishing, but also face high costs for electricity generated by non-renewable sources (Hochstein, 2015). Climate change is threatening the viability of food resources through physical, biological, and geochemical shifts. It is necessary to consider the additional impact that hydropower development and management of existing facilities has on the habitat of fish and game in a changing climate, even when it provides cheaper electricity. 


\section{Predicting far northern hydrology and estimating uncertainty}

\subsection{Long-term projections}

Long-term climate projections from global climate models (GCMs) have now been recognized as valuable for both existing and future hydropower infrastructure planning and management (Viers, 2011). Traditional water supply projections lead to different conclusions than projections that take into account climate change, including the range of plausible futures, or "uncertainty" around the model projections (Barsugli et al., 2012; Hamlet, 2011). The following general techniques are used in recent work to predict future hydrologic regimes (Clark et al., 2015; Hagemann et al., 2013; Barsugli et al., 2012; Chen et al., 2012, 2014; Balsamo et al., 2009, 2011; Brekke et al., 2011; Koutsoyiannis et al., 2009; Lawrence and Hisdal, 2011; Frigon et al., 2007; Hagg et al., 2006; Bergstrom et al., 2001):

1. using a high-quality baseline historical observational data set that is at least 40 years long;

2. interpolating or "gridding" temperature and precipitation data to the spatial resolution of interest or assimilating these and other data into a reanalysis model to produce gridded fields;

3. applying perturbations, various statistical techniques, or "error bars" around the observations, or using prior knowledge to estimate the observational uncertainty;

4. running multiple GCMs, each either stand-alone or with a regional model nested in a global model, with a variety of different emissions scenarios and forcing data values (ensembles) for the historical period to represent observational uncertainty;

5. downscaling the GCM output to a local scale using statistical or dynamical methods;

6. comparing gridded baseline climatologic observations and model output for the historical period to evaluate model biases;

7. using the GCM output to force a hydrologic model or to perform a fully coupled simulation with river routing;

8. comparing hydrologic model output to runoff observations for the historical period.

These hydrological impact studies are the precursors to understanding climate impacts to hydropower (Jost and Weber, 2012; Pittock, 2010). Hydroclimate models can be used to understand glacier and snowmelt dynamics (Huss et al., 2008; Jonsdottir, 2008; Schaefli et al., 2007; Johannesson, 2006), but they can also be linked with energy market models to understand financial and technical feasibility; economic vulnerability to climate change (Cherry et al., 2005b; Harrison et al., 2003; Harrison and Whittington, 2002); and they can provide a methodological approach to understand tradeoffs (Rheinheimer et al., 2013). Because getting to detailed, precise information at the watershed scale requires intensive effort and significant computing power, these methods have mostly been applied to case studies of particular basins (Bennett et al., 2012; Shrestha et al., 2012 in the Far North). Land surface models within GCMs and regional climate models (RCMs) are another class of model that have been tested and compared for hydrologic applications, and are designed for global domains, but challenges of river routing ( $\mathrm{Li}$ et al., 2013) and other local processes cause these tools to have large uncertainties at the watershed scale (Clark et al., 2015). The hydrologic modeling should also be used to drive models of sediment load for projecting reservoir in-filling and wear and tear on turbines (Toniolo and Schultz, 2005).

National assessments are important for understanding relative hydroclimate vulnerability (Rummukainen et al., 2003; Hurd et al., 1999; Lettenmaier et al., 1999), while basinlevel models can provide more specific projections to inform water management (Döll et al., 2015; Frigon et al., 2007). In several studies of the Colorado River basin, it was found that under most projected climate scenarios, reduced flows in the river result in annual in-stream allocations being met less frequently, along with hydropower production declines (Vano et al., 2010; Rajagopalan et al., 2009; Christensen, 2004). Basin-level studies have also revealed shifts in flow timing and hydropower production (Finger et al., 2012). Hydropower modeling can provide specific information, at the plant level, to assess changing potential due to climate change (Chernet et al., 2013), and tailor management in order to maintain efficient production (Burn and Simonovic, 1996). Plant-level modeling can also integrate electricity market information in order to understand the economic impact of climate change on both the supply and demand for power (Gaudard et al., 2013).

\subsection{Seasonal and shorter-term prediction}

Northern states, countries, and individual utilities vary in the extent to which they use seasonal hydrologic prediction, which may reflect these organizations' existing capacity to utilize future projections as well (Inderberg and Løchen, 2012; Kirkinen et al., 2005). For example, the Alaska Pacific River Forecast Center will use the National Oceanic and Atmospheric Administration (NOAA) Climate Prediction Center seasonal outlook temperature and precipitation products as a general reference during the flood-prone spring river break-up season, but they do not use these products quantitatively to force hydrologic models during the season ahead. Hydro-Quebec and Norsk Hydro (large, semi-public utilities) on the other hand, have considerably more resources to use quantitative hydrologic modeling at the seasonal scale. In the United States, climate- or weather-model-driven seasonal hy- 
drologic forecasting (SHF) is an emerging field, and one still limited to selected regions and a limited number of models (Yuan et al., 2015; Gochis et al., 2014). For hydropower management, however, quantitative seasonal forecasting should be routine and these model simulations will depend on a robust observational network. Ensemble approaches are a typical means for estimating uncertainty for seasonal forecasts and other researchers have innovated methods for quantifying uncertainty in the land surface models through Bayesian and other statistical techniques (Beven et al., 2012; Clark et al., 2011).

Shorter-term, synoptic-scale quantitative prediction of hydroclimate is of high value to facility managers in operations. However the accuracy of these forecasts is unknown in basins with few or no direct observations. With few observations and no quantitative forecasts, operators must rely on their past experiences and qualitative estimates of the impacts of synoptic weather events. During extreme events, such as an unprecedented rain-on-snow storms, managers may not have the past experience to anticipate the necessary operational decision-making. Short-term, coupled hydroclimate prediction systems could provide a valuable source of information for decision makers. Like with longer-term projections, these too need uncertainty estimates.

\subsection{Estimating and reducing uncertainty}

For new, large hydropower projects, it is imperative to conduct a future hydroclimate projection study during the prelicensing phase of the project to determine long-term water supplies and downstream impacts, given all of the climate change complexities noted above. Estimates of uncertainty, or the range of plausible futures, either quantitative or qualitative, should be an essential component of these studies. For example, studies ordered by the Federal Energy Regulatory Commission (FERC, 2013a, b) for the pre-licensing phase of the proposed Susitna-Watana dam in central Alaska did not include a detailed analysis of climate risks or uncertainty, as had been requested by NOAA/NMFS (2012). The license applicant, the Alaska Energy Authority (AEA), funded a study to assess glacial and hydrologic regimes that went above and beyond what the FERC ordered (FERC, 2013c), but this study only used a single climate model for its analysis (Wolken et al., 2015). This leaves stakeholders with only a single estimate of future runoff and little sense of the uncertainty of these estimates. Brekke et al. (2011) described methods to include the uncertainty, or spread, projected by GCMs, the bias in climate models, and to account for local terrain and weather (for example through downscaling or high-resolution hydrologic modeling).

Two technological bottlenecks slow progress towards reducing uncertainty in this field: (1) accuracy and representativeness of hydroclimate observations in time and space and (2) quality and fidelity of models (Kundzewicz and Stakhiv, 2010; Hawkins and Sutton, 2009). These two issues are of particular concern in the Far North because they also make it difficult to understand natural climate variability. Relative to the contiguous United States or mainland Europe, the Far North is particularly data poor, with respect to hydroclimate observations (Key et al., 2015; McClelland et al., 2015 and references therein). The shortcomings in estimates of ET and precipitation have already been discussed. Very little is known or understood about groundwater in the Far North, or how it might be changing because observations are so sparse (Bense et al., 2009; Moran and Solin, 2006). There are considerable unknowns about the timing of glacial retreat, thawing of permafrost, and change in subsurface storage of water (Walsh et al., 2014; Murray et al., 2010).

Climate models also represent the climate system imperfectly, particularly the complexities in the Far North; this is another source of uncertainty. The global trajectory of greenhouse gas emissions into the future is another unknown. Many authors have characterized and summarized these uncertainties over the past decade of literature (Eum et al., 2014; Kunreuther et al., 2013 and references therein; Lofgren et al., 2013; Clark et al., 2011). For example, Wilby and Dessai (2010) described a cascading pyramid of uncertainty wherein each step away from the global climate model (towards regional, impact, and adaptations models) generates more and more permutations of reality and thus, uncertainty. While this framework may seem daunting, they also use it to suggest concrete measures to adapt water resource management to climate change.

In order to improve predictions of far northern hydrology and estimate uncertainty for hydropower planning we need to (1) improve, expand, and sustain observational systems while (2) continuing to improve global and regional hydroclimate models and output the necessary model parameters needed for decision-making. Observational systems include not just measurements of precipitation and discharge but also topographic data sets and dynamic maps of subsurface features, such as permafrost and groundwater. To improve models, process studies must occur in study basins, but then techniques learned in these efforts must propagate into the models. Local downscaling is an essential component of hydrologic projections, but (3) a better quantitative evaluation of the uncertainty of these downscaled products is needed, based on emerging statistical techniques and ensemble simulations (Barsugli et al., 2013; Chen et al., 2012, 2014; Dibike et al., 2008). 
4 Best practices for integration of climate change science into project planning and management

\subsection{Amass high-quality information via baseline observations, process studies, and hydroclimate modeling}

For proposed and existing hydropower projects, project managers need to pull together a meaningful body of knowledge about the hydroclimate system, employing all of the techniques described in the preceding section. In doing so, it may be necessary to evaluate and potentially deploy additional observational systems and, if appropriate, keep them running over the lifespan of the project for decision support. At the current time, researchers are most confident about historical trends in climate in the Far North that are derived from long-term, consistently instrumented stations or remote sensing records (Curran et al., 2012). In general, these observations are limited to air temperature, ground temperature, snow-covered area, and river discharge at just a few stations, or they have limited temporal coverage. From the subset of these records that cover at least 40 years or more, meaningful statistics can be generated about the historic patterns of variability and change; 60-80 years of data are even better. The more that observational networks expand and improve to accurately measure ET, precipitation, groundwater, and water storage over long periods of time and in many locations, the more confident we will be in our knowledge of water resource availability.

Historic observations provide a basis to predict future change, given what we know about other mechanisms in the Earth system, which may affect how these future climate trajectories unfold. Unfortunately, the 2 years of river discharge measurements required for a standard water use permit in the state of Alaska, for example, provide almost no information about the variability of that water source on interannual, decadal, and multi-decadal timescales. Models calibrated with long-term, high-quality, historic data with fine temporal and spatial scales are the most robust, quantitative way to predict water resources into the future, as well as provide uncertainty estimates (Pechlivanidis et al., 2011).

Detailed hydrologic process studies in the project basin are also necessary in the Far North to ensure that appropriate models are developed and continue to be refined. These would include observations and modeling of small-scale systems impacting a resource watershed such as those from glacier, groundwater, permafrost, surface water, and meteorological inputs. These process studies help researchers and resource managers understand how watersheds respond to changes in temperature, precipitation, vegetation, etc., and give experts the confidence and information necessary to make qualitative and quantitative predictions about future availability of water resources.

The modeling techniques described above in the long-term projections subsection should be employed to further push regional hydroclimate modeling capabilities. While Earth system modeling has focused on regional model development, and polar modeling has made progress in this respect (e.g., Regional Arctic System Model, http://www.oc. nps.edu/NAME/RASM.htm), these fully coupled polar models are still relatively new and are used to simulate domains with a land surface resolution of $\sim 50 \mathrm{~km}$ grid cells. Global Earth system models still do not simulate hydrology realistically in the Far North, because they do not have detailed glacier, groundwater, and permafrost physics on the spatial scales necessary for water resource planning or management (Wolken et al., 2015). These physically based approaches are necessary to reduce uncertainty about hydrologic processes a decade or more into the future and can provide both qualitative and quantitative information. Decision makers need long-term hydroclimate projections over the managed basin updated at least every 5 years, as data records grow and the models advance. A release of each new generation of IPCC climate model outputs, every $4-5$ years, would be a logical trigger for new downscaled runoff estimates. This information is needed in the management of the water resources themselves, but also upstream and downstream impacts on habitat and ecosystems. For existing hydropower projects, hydroclimate projections should be used to consider structural, operational, and management adaptations, which are discussed in the next subsection.

\subsection{Create structural and management adaptations for hydropower under climate change}

A number of structural or operational adaptation practices could help integrate climate change science into project planning and management (ICOLD, 2013; Arsenault et al., 2013). These include

1. A more adaptive and regionalized hydropower facility licensing process. The current licensing process in the United States has not been responsive to climate change impacts (Viers, 2011), especially when management procedures such as storage and spill thresholds are firm and fixed. Several suggestions that have emerged in the literature include adaptive licensing, shorter-term licenses, and more integrative licenses across basins. Explicit adaptive licensing could include specific operational responses to thresholds (Rheinheimer et al., 2013) or more frequent assessment of performance (ICOLD, 2013; Brekke et al., 2009; Madani, 2011). Brekke et al. (2009) and these other studies reiterate that we can no longer assume a stationary hydrological future and licensing structures need to reflect this. Methods described by Brekke et al. (2011) could be used in FERCordered studies (in the United States) as part of the licensing process to include the uncertainty, or spread, projected by GCMs in order to have estimates of future reservoir inflows that are representative of the range 
and uncertainty across climate models. Study requests to FERC have included such methods, but FERC has not yet fully accepted them (NOAA/NMFS, 2012, 2016). Shorter contracts for hydropower licensing could allow operators to better consider and integrate climate change impacts on a regular basis (Viers, 2011). Reopening licenses is not an adequate adaptation; changes in hydrology that impact hydropower project operations can be projected at a useful level during project prelicensing and re-licensing processes and should be addressed at those stages. Finally, it is important to promote coordination of water management across projects so that cumulative effects within a basin are considered (Viers, 2011). This more regional approach would allow for greater balancing between ecological and production-related goals (Brown et al., 2015; Viers, 2011, Marttila et al., 2005). Robust strategies in the licensing and operations (i.e., strategies that will last for more than a year or two under a variety of different climate and economic conditions) may have an even bigger impact than making more precise predictions (Wilby, 2010).

2. Flexible and adaptable operations rules. One of the most consistent messages in the literature related to climate change and hydropower is that operations need to adapt their rules if they want to manage for optimal productivity (Gaudard et al., 2013; Vicuna et al., 2011; Madani, 2010; Minville et al., 2009, 2010a, b; Raje and Mujumdar, 2010; Alfieri et al., 2006; Burn and Simonovic, 1996). For example, operational rules should allow for management changes to facilities utilizing glacially fed basins, once the glaciers have significantly receded and glacial melt has declined. If drought frequency increases 30 years after a project was built, a new operating paradigm is needed. This has been supported by studies that have shown that there is a decrease in performance of hydropower systems if management is rigid and does not adapt to changing conditions (Mehta et al., 2011; Perez-Diaz and Wilhelmi, 2010; Minville et al., 2009, 2010a, b; Schaefli et al., 2007; Robinson, 1997).

3. Training for hydropower managers. Water resource managers need support to more adequately incorporate climate change projections into the management of hydropower plants. Water managers often lack guidance about how to best integrate climate change into decision-making; detailed guidance and training should be developed through collaborations between FERC, hydropower trade organizations, (internationally) the World Meteorological Organization, and the World Bank. Several studies have called for a better transfer of information from climate scientists to water managers (Lund, 2015; Milly et al., 2008; Oki and Kanae,
2006). This transfer can be accomplished by boundary organizations ${ }^{4}$, which can bridge science and practice by translating projections in a way that can inform decision-making (Gordon et al., 2016; Miller et al., 2001; Cash et al., 2001; Lowrey et al., 2009). This could include higher-resolution and more faithful models (i.e., more accurate for the correct physical reasons), a stable institutional platform for information exchange, and better communication about the precise needs of decision makers. Training should also address better understanding about the uncertainty inherent in projections. Uncertainty is one of the reasons that climate forecasts are rarely used by managers (Rayner et al., 2005), despite these forecasts' utility. However, relying on the status quo of assuming hydrologic stationarity is counterproductive because the effects of climate change are evident already. While uncertainty cannot be fully overcome, it is possible to make wise management decisions despite this uncertainty (Ouranos, 2008).

\subsection{Engage hydropower-supporting institutions to convey climate change guidance}

There are several international organizations that are involved in different aspects of hydropower advocacy, information, development, and planning. These entities might be well positioned to act as boundary organizations to incorporate climate change information in project scoping and management. The International Hydropower Association (IHA) is a non-profit organization and global network working to advance sustainable hydropower. However, this organization has shown few tangible efforts to explore climate change impacts on hydropower. While IHA acknowledges that adaptation to climate change is a component of sustainable hydropower resource and reservoir planning (IHA, 2010), their recent conferences have had few sessions on climate change and hydropower. Those sessions that did address these topics focused more on climate change mitigation than climate change adaptation (IHA, 2013). Locher et al. (2010) reviewed IHA's recently published sustainability assessment protocol (IHA, 2010), and found that it pays insufficient attention to climate change and its impact on hydropower. Finally, the IHA (2013) report describes a new protocol for measuring carbon emissions from reservoirs, but has little other mention of climate change.

The World Commission on Dams (WCOD) is a global multi-stakeholder body initiated by the World Bank and World Conservation Union in response to opposition to large dam projects. A recent report discussed how climate change would likely reduce dam safety through an increase in extreme weather events (WCOD, 2000). They recommend that planning and ongoing monitoring should include modeling

\footnotetext{
${ }^{4}$ These are organizations whose central purpose is to create and sustain meaningful and mutually beneficial links between knowledge producers and users (Guston, 2001).
} 
potential changes in flow due to climate change (WCOD, 2000). The International Centre for Hydropower (ICH) is an international association of companies and organizations that are active in all aspects of hydropower generation and supply. Recent ICH conference proceedings suggest that climate change will impact all hydropower development and cannot be ignored (ICH, 2016). Several sessions on hydropower and climate change suggest growing awareness of the effects of climate change on hydropower development and operations.

The International Energy Agency (IEA) is an organization that works to ensure reliable, clean and affordable energy for its 28 member countries. IEA tracks global energy statistics, such as hydropower generation and consumption, making those data freely available for analysis. There has been a shift in their attention to climate change, but few concrete actions have been taken. In 2000, there was no clear direction or policy on climate change and hydropower within IEA according to their publications, while by 2013 it was mentioned as a key priority for moving forward within the organization (IEA, 2013).

The World Bank is another organization that is involved in the funding of development projects around the globe, including hydropower. The World Bank has described how investments in the water sector are vulnerable to climate change (World Bank, 2009). In response, they have stated that infrastructure should be designed using the best climate change information available, which should be taken into account when planning new projects (World Bank, 2009). They have found that traditional water supply projections lead to different conclusions than projections that take climate change into account (Ilimi, 2007).

Finally, the International Commission on Large Dams (ICOLD) is a professional organization, whose goal is to set guidelines and standards for building dams that are safe, efficient, economical, environmentally sound, and equitable. A technical committee is currently drafting a report on climate change, dams, reservoirs and water resources (ICOLD, 2013). This report, if completed, will describe the risks and uncertainties related to climate change and hydropower, present an impact assessment framework, describe other drivers of change, discuss hydropower emissions, and provide suggestions and strategies for adaptation from the point of view of a pro-dam organization.

These types of hydropower-supporting organizations - regardless of how central advocacy is to their mission - could all benefit from having the best available information about climate change and helping convey it to stakeholders. Because stakeholders are accustomed to getting information, guidance, and training from these organizations, extending that support to include climate change science could be highly effective.

\section{Summary and conclusions}

In summary

1. The climate of the Far North is changing. It is projected to get warmer and wetter here through the end of the century. Permafrost will continue to thaw, landlocked glaciers will continue to recede, and the surfacesubsurface partitioning of water fluxes and storage will change. We have reviewed how some of these hydroclimate changes will likely impact hydropower in far northern regions, how this information relates to planning and management, and we have described the stateof-the-art techniques for predicting and estimating uncertainty.

2. In order to improve predictions of far northern hydrology and estimating uncertainty for hydropower planning, it is necessary to improve, expand, and sustain observational systems while continuing to improve global and regional hydroclimate models. A better quantitative evaluation of the uncertainty of these products is also needed, based on emerging statistical techniques.

3. Best practices in hydropower planning include having high-quality information available to stakeholders from observations, process studies, and hydroclimate modeling. It is imperative to create structural and management adaptations for hydropower under climate change. These include a more adaptive and regional hydropower facility licensing process, flexible and adaptable operations rules, and training for operators). Finally, hydropower-supporting institutions should be engaged as boundary organizations to convey climate change guidance.

4. We have shown that hydropower infrastructure is vulnerable to climate change. For new, large projects, such as the proposed Susitna-Watana dam in Alaska, it is essential to incorporate climate change, the complexities noted above, and uncertainty analysis into the research during the scoping phase to determine long-term water supplies and downstream impacts.

The changing climate and hydrology of the Far North is undoubtedly complex. While the hydroclimate research community is aware of shortcomings in models and data sets - and is actively improving these tools - techniques have emerged for hydrologic prediction and uncertainty analysis that are currently employable in water resource management (Ray and Brown, 2015). We need to continue to improve our baseline observations, conduct process studies that help improve models, quantify uncertainties where possible, and also identify when data are too sparse or of too poor quality to use for decision-making. 
Best practices are just that: practices based on the best available information for hydropower planning and operations. Is this information perfect? Absolutely not, but the two pertinent questions are (1) is this information worth the cost it takes to generate and (2) is it good enough for decision-making. For planned and existing projects worth millions or billions of dollars, hydroclimate prediction and uncertainty estimation require a tiny fraction of the cost of maintaining the facility. Given the potential impacts to hydropower production and efficiency, adaptation to climate change should be considered in the development of new hydropower projects (Kaunda et al., 2012; Ouranos, 2008).

Is the best available climate change information good enough for decision-making? Yes, and it can be used in the same risk assessment framework that is currently used in other aspects of hydropower planning, such as the assessment of risks associated with earthquakes or flooding (Patel and Singhal, 2015). For those facilities built 30 to 50 years ago, we did not have the technology to adequately project climate change. It is clear from the impacts of drought in the western United States, and other regions, that climate change is already affecting existing hydropower projects (Andreadis and Lettenmaier, 2006; Mote, 2006). If hydropower managers were to ignore the best available hydroclimate information today, the cost to society could be quite high. Building flexible adaptations to climate change into hydropower planning and management is in the best interest of all who want to see these projects sustained or expanded.

Author contributions. Jessica E. Cherry prepared the bulk of the manuscript and crafted the paper's outline and arguments. Corrie Knapp performed a literature review of many related social science and physical publications, which was woven throughout the paper. Sarah Trainor helped guide Corrie Knapp's literature review and helped improve the writing. Andrea J. Ray helped identify appropriate literature, refine the paper's arguments, and helped improve the writing. Molly Tedesche performed a preliminary literature review focused on hydrology and helped proofread the final paper. Susan Walker helped identify components to make the paper relevant for stakeholder decision-making and proofread the final paper.

Acknowledgements. Jessica E. Cherry wishes to thank the National Oceanic and Atmospheric Administration-National Marine Fisheries Service (NOAA-NMFS) for financial support of this effort (award no. HA-133F-12-SE-2460) and Lily Cohen at the University of Alaska Fairbanks (UAF) for helping organize the references. Molly Tedesche, Corrie Knapp, and Sarah Trainor acknowledge financial support from NOAA-NMFS under that same award number. Sarah Trainor also acknowledges support from NOAA Climate Program Office grant NA11OAR4310141 through the Alaska Center for Climate Assessment and Policy at UAF, Alaska EPSCoR NSF award no. OIA-1208927, and the state of Alaska. Ray's participation in this effort was supported in-kind by the NOAA/ESRL Physical Sciences Division and Walker was supported in-kind by NOAA-NMFS. The authors wish to thank ACCAP and IARC for covering the cost of page charges.

Edited by: S. Uhlenbrook

Reviewed by: two anonymous referees

\section{References}

Agrawala, S., Raksakulthai, V., Aalst, M., Larsen, P., Smith, J., and Reynolds, J.: Development and climate change in Nepal: Focus on water resources and hydropower, Organization for Economic Cooperation and Development, Paris, France, 2003.

Alaska Climate Research Center: http://climate.gi.alaska.edu/, last access: 4 April 2016.

Alaska Energy Authority (AEA): Susitna-Watana Project: http:// www.susitna-watanahydro.org/, last access: 8 February 2016.

Alaska Energy Data Inventory (AEDI): http://www. akenergyinventory.org, last access: 8 February 2016.

Alfieri, L., Perona, P., and Burlando, P.: Optimal water allocation for an alpine hydropower system under changing scenarios, Water Resour. Manag., 20, 761-778, 2006.

Andreadis, K. M. and Lettenmaier, D. P.: Trends in 20th century drought over the continental United States, Geophys. Res. Lett., 33, L10403, doi:10.1029/2006GL025711, 2006.

Andrishak, R. and Hicks, F.: Simulating the effects of climate change on the ice regime of the Peace River, Can. J. Civil Eng., 35, 461-472, 2008.

Arendt, A. A., Echelmeyer, K. A., Harrison, W. D., Lingle, C. S., and Valentine, V. B.: Rapid wastage of Alaska glaciers and their contribution to rising sea level, Science, 297, 382-386, 2002.

Arendt, A. A., Walsh, J., and Harrison, W.: Changes of Glaciers and Climate in Northwestern North America during the Late Twentieth Century, J. Climate, 22, 4117-4134, doi:10.1175/2009JCLI2784.1, 2009.

Arsenault, R., Brissette, F., Malo, J. S., Minville, M., and Leconte, R.: Structural and Non-Structural Climate Change Adaptation Strategies for the Pribonka Water Resource System, Water Resour. Manag., 27, 2075-2087, 2013.

Balsamo, G., Viterbo, P., Beljaars, A., van den Hurk, B., Hirschi, M., Betts, A. K., and Scipal, K.: A revised hydrology for the ECMWF model: Verification from field site to terrestrial water storage and impact in the integrated forecast system, J. Hydrometeorol., 10, 623-643, doi:10.1175/2008JHM1068.1, 2009.

Balsamo, G., Pappenberger, F., Dutra, E., Viterbo, P., and van den Hurk, B.: A revised land hydrology in the ECMWF model: A step towards daily water flux prediction in a fully-closed water cycle, Hydrol. Process., 25, 1046-1054, doi:10.1002/hyp.7808, 2011.

Barnett, T. P., Adam, J. C., and Lettenmaier, D. P.: Potential impacts of a warming climate on water availability in snow-dominated regions, Nature, 438, 303-309, 2005.

Barsugli, J. J., Vogel, J., Kaatz, L., Smith, J., Waage, M., and Anderson, C. A.: Two faces of uncertainty: climate science and water utility planning methods, J. Water Res. Pl.-ASCE, 138, 389-395, 2012.

Barsugli, J. J, Guentchev, G., Horton, R. M., Wood, A., Mearns, L. O., Liang, X. Z., Winkler, J. A., Dixon, K., Hayhoe, K., Rood, R. B., Goddard, L., Ray, A. J., Buja, L., and Ammann, C.: The 
Practitioner's Dilemma: How to Assess the Credibility of Downscaled Climate Projections, Eos T. Am. Geophys. Un., 94, 42425, 2013.

Beniston, M.: Impacts of climatic change on water and associated economic activities in the Swiss Alps, J. Hydrol., 412, 291-296, 2012.

Bennett, K. E. and Walsh, J. E.: Spatial and temporal changes in indices of extreme precipitation and temperature for Alaska, Int. J. Climatol., 35, 1434-1452, doi:10.1002/joc.4067, 2015.

Bennett, K. E., Werner, A. T., and Schnorbus, M.: Uncertainties in hydrologic and climate change impacts analyses in headwater basins of British Columbia, J. Climate, 25, 5711-5730, 2012.

Bense, V. F., Ferguson, G., and Kooi, H.: Evolution of shallow groundwater flow systems in areas of degrading permafrost, Geophys. Res. Lett., 36, L22401, doi:10.1029/2009GL039225, 2009.

Bergstrom, S., Carlsson, B., Gardelin, M., Lindstrom, G., Pettersson, A., and Rummukainen, M.: Climate change impacts on runoff in Sweden - assessments by global climate models, dynamical downscaling and hydrological modeling, Climate Res., 16, 101-112, 2001.

Beven, K., Smith, P., Westerberg, I., and Freer, J.: Comment on "Pursuing the method of multiple working hypotheses for hydrological modeling" by Clark et al., Water Resour. Res., 48, W11801, doi:10.1029/2012WR012282, 2012.

Bliss, A., Hock, R., and Radić, V.: Global response of glacier runoff to twenty-first century climate change, J. Geophys. Res.-Earth, 119, 717-730, 2014.

Bolch, T., Peters, J., Yegorov, A., Pradhan, B., Buchroithner, M., and Blagoveshchensky, V.: Identification of potentially dangerous glacial lakes in the northern Tien Shan, Nat. Hazards, 59, 1691-1714, 2011.

Brekke, L., White, K., Olsen, J. R., Townsley, E., Williams, D., Hanbali, F., Hennig, C., Brown, C., Raff, D., and Wittler, R.: Addressing Climate Change in Long-Term Water Resources Planning and Management User Needs for Improving Tools and Information, US Army Corps of Engineers Civil Works Technical Series CWTS-10-02, http://www.usbr.gov/climate/userneeds/ (last access: 4 April 2016), 2011.

Brekke, L. D., Maurer, E. P., Anderson, J. D., Dettinger, M. D., Townsley, E. S., Harrison, A., and Pruitt, T.: Assessing reservoir operations risk under climate change, Water Resour. Res, 45, W04411, doi:10.1029/2008WR006941, 2009.

Brown, C. M., Lund, J. R., Cai, X., Reed, P. M., Zagona, E. A., Ostfeld, A., Hall, J., Characklis, G. W., Yu, W., and Brekke, L.: The future of water resources systems analysis: Toward a scientific framework for sustainable water management, Water Resour. Res., 51, 6110-6124, doi:10.1002/2015WR017114, 2015.

Burn, D. H. and Simonovic, S. P.: Sensitivity of Reservoir Operation Performance to Climatic Change, Water Resour. Manag., 10, 463-478, 1996.

Callaghan, T. V., Johansson, M., Brown, R. D., Groisman, P. Y., Labba, N., Radionov, V., Barry, R. G., Bulygina, O. N., Essery, R. L. H., Frolov, D. M., Golubev, V. N., Grenfell, T. C., Petrushina, M. N., Razuvaev, V. N., Robinson, D. A., Romanov, P., Shindell, D., Shmakin, A. B., Sokratov, S. A., Warren, S., and Yang, D. Q.: The Changing Face of Arctic Snow Cover: A Synthesis of Observed and Projected Changes, Ambio, 40, 17-31, $2011 \mathrm{a}$.

Callaghan, T. V., Johansson, M., Brown, R. D., Groisman, P. Y., Labba, N., Radionov, V., Bradley, R. S., Blangy, S. Bulygina, O.
N., Christensen, T. R., Colman, J. E., Essery, R. L. H., Forbes, B. C., Forchhammer, M. C., Golubev, V. N., Honrath, R. E., Juday, G. P., Meshcherskaya, A. V., Phoenix, G. K., Pomeroy, J., Rautio, A., Robinson, D. A., Schmidt, N. M., Serreze, M. C., Shevchenko, V. P., Shiklomanov, A. I., Shmakin, A. B., Skold, P., Sturm, M., Woo, M. K., and Wood, E. F.: Multiple Effects of Changes in Arctic Snow Cover, Ambio, 40, 32-45, 2011 b.

Carey, S. K., Boucher, J. L., and Duarte, C. M.: Inferring groundwater contributions and pathways to streamflow during snowmelt over multiple years in a discontinuous permafrost subarctic environment (Yukon, Canada), Hydrogeol. J., 21, 67-77, 2013.

Cash, D. W.: In Order to Aid in Diffusing Useful and Practical Information: Agricultural Extension and Boundary Organizations, Science, Technology and Human Values, 26, 431-53, 2001.

Chen, J., Brissette, F. P., and Leconte, R.: Coupling statistical and dynamical methods for spatial downscaling of precipitation, Climatic Change, 114, 509-526, 2012.

Chen, J., Brissette, F. P., and Leconte, R.: Assessing regressionbased statistical approaches for downscaling precipitation over North America, Hydrol. Process., 28, 3482-3504, 2014.

Chernet, H. H., Alfredsen, K., and Killingtveit, A.: The impacts of climate change on a Norwegian high-head hydropower system, J. Water Clim. Change, 4, 17-37, 2013.

Cherry, J. E., Tremblay, L.-B, Déry, S., and Stieglitz, M.: Solid precipitation reconstruction using snow depth measurements and a land surface hydrology model, Water Resour. Res., 41, W09401, doi:10.1029/2005WR003965, 2005a.

Cherry, J. E., Cullen, H., Visbeck, M., Small, A., and Uvo, C.: Impacts of the North Atlantic Oscillation on Scandinavian hydropower production and energy markets, Water Resour. Manag., 19, 673-691, 2005b.

Cherry, J. E., Tremblay, L.-B., Stieglitz, M., Gong, G., and Déry, S.: Development of the Pan-Arctic Snowfall Reconstruction: new land-based solid precipitation estimates for 1940-1999, J. Hydrometeorol., 8, 1243-1263, 2007.

Christensen, J. H., Krishna Kumar, K., Aldrian, E., An, S.-I., Cavalcanti, I. F. A., de Castro, M., Dong, W., Goswami, P., Hall, A., Kanyanga, J. K., Kitoh, A., Kossin, J., Lau, N.-C., Renwick, J., Stephenson, D. B., Xie, S.-P., and Zhou, T.: Climate Phenomena and their Relevance for Future Regional Climate Change, in: Climate Change 2013: The Physical Science Basis. Contribution of Working Group I to the Fifth Assessment Report of the Intergovernmental Panel on Climate Change, edited by: Stocker, T. F., Qin, D., Plattner, G.-K., Tignor, M., Allen, S. K., Boschung, J., Nauels, A.,Xia, Y., Bex, V., and Midgley, P. M., Cambridge University Press, Cambridge, United Kingdom and New York, NY, USA, 2013.

Christensen, N. S., Wood, A. W., Voisin, N., Lettenmaier, D. P., and Palmer, R. N.: The effects of climate change on the hydrology and water resources of the Colorado River basin, Climatic Change, 62, 337-363, 2004.

Clark, M. P., Kavetski, D., and Fenicia, F.: Pursuing the method of multiple working hypotheses for hydrological modeling, Water Resour. Res., 47, W09301, doi:10.1029/2010WR009827, 2011.

Clark, M. P., Fan, Y., Lawrence, D. M., Adam, J. C., Bolster, D., Gochis, D. J., Hooper, R. P., Kumar, M., Leung, L. R., Mackay, D. S., Maxwell, R. M., Shen, C., Swenson, S. C., and Zeng, X.: Improving the representation of hydrologic processes 
in Earth System Models, Water Resour. Res., 51, 5929-5956, doi:10.1002/2015WR017096, 2015.

Cohen, J. L., Furtado, J. C., Barlow, M., Alexeev, V. A., and Cherry, J. E.: Asymmetric seasonal temperature trends, Geophys. Res. Lett., 39, L04705, doi:10.1029/2011GL050582, 2012a.

Cohen, J. L., Furtado, J. C., Barlow, M., Alexeev, V. A., and Cherry, J. E.: Arctic warming, increasing snow cover and widespread boreal winter cooling, Environ. Res. Lett., 7, 014007 , doi:10.1088/1748-9326/7/1/014007, 2012b.

Conner, A. M. and Francfort, J. E.: U.S. Hydropower Resource Assessment for Alaska. Idaho National Lab, whitepaper DOE/ID10430(AK), http://hydropower.inl.gov/resourceassessment/pdfs/ states/ak.pdf (last access: 3 April 2016), 1997.

Curran, J. H.: Streamflow record extension for selected streams in the Susitna River Basin, Alaska: US Geological Survey Scientific Investigations Report, 2012-5210, 36, 2012.

Dahlke, H. E., Lyon, S. W., Stedinger, J. R., Rosqvist, G., and Jansson, P.: Contrasting trends in floods for two sub-arctic catchments in northern Sweden - does glacier presence matter?, Hydrol. Earth Syst. Sci., 16, 2123-2141, doi:10.5194/hess-16-21232012, 2012.

Dibike, Y. B., Gachon, P., St-Hilaire, A., Ouarda, T. B. M. J., and Nguyen, V. T.-V.: Uncertainty analysis of statistically downscaled temperature and precipitation regimes in Northern Canada, Theor. Appl. Climatol., 91, 149-170, 2008.

Döll, P., Jiménez-Cisneros, B., Oki, T., Arnell, N. W., Benito, G., Cogley, J. G., Jiang, T., Kundzewicz, Z. W., Mwakalila, S., and Nishijima, A.: Integrating risks of climate change into water management, Hydrolog. Sci. J., 60, 4-13, doi:10.1080/02626667.2014.967250, 2015.

Energy Information Administration (EIA): http://www.eia.gov/ electricity/annual/ (last access: 1 March 2015), 2015.

Eum, H. I., Dibike, Y., and Prowse, T.: Uncertainty in modeling the hydrologic responses of a large watershed: a case study of the Athabasca River basin, Canada, Hydrol. Process., 28, 42724293, 2014.

Federal Energy Regulatory Commission (FERC): Study Plan Determination for the Susitna-Watana Hydroelectric Project, Project No. P-14241, 1 February 2013, http://www.susitna-watanahydro. org/wp-content/uploads/2015/11/20130201_FERC_SPD.pdf (last access: 1 June 2016), 2013a.

Federal Energy Regulatory Commission (FERC): Study Plan Determination on 14 remaining studies for the Susitna-Watana Hydroelectric Project, Project No. P-14241, 1 April 2013, http://www.susitna-watanahydro.org/wp-content/uploads/2015/ 11/20130401_FERC_SPD14remainingStudies.pdf (last access: 1 June 2016), 2013b.

Federal Energy Regulatory Commission (FERC): Director's Formal Study Dispute Determination for the Susitna-Watana Hydroelectric Project, Project No. P-14241, 26 April 2013, http://www.susitna-watanahydro.org/wp-content/uploads/2015/ 11/20130426_FERC_DirectorsDisputeDetermination.pdf, 2013c.

Fenner, R. A.: Ice, Snow and Water: impacts of climate change on California and Himalayan Asia, UCSD Sustainability Solutions Institute Publication Series, http://escholarship.org/uc/item/ 8wh378h7 (last access: 3 April 2016), 2009.

Finger, D., Heinrich, G., Gobiet, A., and Bauder, A.: Projections of future water resources and their uncertainty in a glacierized catchment in the Swiss Alps and the subsequent effects on hydropower production during the 21 st century, Water. Resour. Res., 48, W03903, doi:10.1029/2011WR010733, 2012.

Francis, J. A. and Vavrus, S. J.: Evidence for a wavier jet stream in response to rapid Arctic warming, Environ. Res. Lett., 10, 014005, doi:10.1088/1748-9326/10/1/014005, 2015.

Frigon A., Slivitzky, M., Caya, D., and Roy, R.: Construction of hydro-climatic projections and first-order estimation of their associated uncertainties from Regional Climate Model simulations: Application to water management of hydropower reservoirs in Quebec, La Houille Blanche, 6, 97-103, doi:10.1051/lhb:2007089, 2007.

Gallucci, M.: Solar and wind power poised to overtake hydropower as largest source of U.S. Renewable Electricity Generation, International Business Times, 1 August 2014.

Gaudard, L., Gilli, M., and Romerio, F.: Climate Change Impacts on Hydropower Management, Water Resour. Manag., 27, 51435156, 2013.

Gebre, S., Alfredsen, K., Lia, L., Stickler, M., and Tesaker, E.: Review of Ice Effects on Hydropower Systems, J. Cold Reg. Eng., 27, 196-222, 2013.

Genet, H., Oberbauer, S. F., Colby, S. J., Staudhammer, C. L., and Starr, G.: Growth responses of Sphagnum hollows to a growing season lengthening manipulation in Alaskan Arctic tundra, Polar Biol., 36, 41-50, 2013.

Georgakakos, A. P., Fleming, P., Dettinger, M., Peters-Lidard, C., Richmond, T. C., Reckhow, K., White, K., and Yates., D.: Water Resources Chapter, National Climate Assessment, http://ncadac. globalchange.gov (last access: 15 April 2015), 2014.

Gochis, D. J., Yu, W., and Yates, D. N.: The WRF-Hydro model technical description and user's guide, version 2.0, NCAR Technical Document, http://www.ral.ucar.edu/projects/ wrf_hydro (last access: 15 April 2015), 120 pp., 2014.

Gordon, E., Dilling, L., McNie, E., and Ray, A. J., Parris, A. S., Garfin, G. M., Dow, K., Meyer, R., and Close, S. L.: 11. Navigating scales of knowledge and decision-making in the Intermountain West: implications for science policy, in: Climate in Context: Science and Society Partnering for Adaptation, John Wiley \& Sons, Ltd, Chichester, UK, 235-254, ISBN 9781118474792 , 2016.

Gurnell, A. M.: Sediment yield from Alpine glacier basins, in: Sediment and Water Quality in River Catchments, edited by: Foster, I. D. L., Gurnell, A. M., and Webb, B. W., Wiley, New York, 407-435, 1995.

Guston, D. H.: Boundary Organizations in Environmental Policy and Science: An Introduction, Sci. Technol. Hum. Val., 26, 399408, 2001

Hagemann, S., Chen, C., Clark, D. B., Folwell, S., Gosling, S. N., Haddeland, I., Hanasaki, N., Heinke, J., Ludwig, F., Voss, F., and Wiltshire, A. J.: Climate change impact on available water resources obtained using multiple global climate and hydrology models, Earth Syst. Dynam., 4, 129-144, doi:10.5194/esd4-129-2013, 2013.

Hagg, W., Braun, L. N., Weber, M., and Becht, M.: Runoff modelling in glacierized Central Asian catchments for present-day and future climate, Nord. Hydrol. 37, 93-105, 2006.

Hamlet, A. F.: Assessing water resources adaptive capacity to climate change impacts in the Pacific Northwest Region of 
North America, Hydrol. Earth Syst. Sci., 15, 1427-1443, doi:10.5194/hess-15-1427-2011, 2011.

Hamududu, B. and Killingtveit, A.: Assessing Climate Change Impacts on Global Hydropower, Energies, 5, 305-322, 2012.

Harrison, G. P. and Whittington, H. W.: Vulnerability of hydropower projects to climate change, IEEEE P.-Gener. Transm. D., 149, 249-255, 2002.

Harrison, G. P., Whittington, H. W., and Wallace, A. R.: Climate change impacts on financial risk in hydropower projects, IEEE T. Power Syst., 18, 1324-1330, 2003.

Harrison, W., Drage, B., Bredthauer, S., Johnson, D., Schoch, C., and Follet, A.: Reconnaissance of the Glaciers of the Susitna River Basin in Connection with Proposed Hydroelectric Development, Ann. Glaciol., 4, 99-104, 1983.

Hansen, J., Ruedy, R., Sato, M., and Lo, K.: Global surface temperature change, Rev. Geophys., 48, RG4004, doi:10.1029/2010RG000345, 2010.

Hartmann, D. L., Klein Tank, A. M. G., Rusticucci, M., Alexander, L. V., Brönnimann, S., Charabi, Y., Dentener, F. J., Dlugokencky, E. J., Easterling, D. R., Kaplan, A., Soden, B. J., Thorne, P. W., Wild, M., and Zhai, P. M.: Observations: Atmosphere and Surface, in: Climate Change 2013: The Physical Science Basis. Contribution of Working Group I to the Fifth Assessment Report of the Intergovernmental Panel on Climate Change, edited by: Stocker, T. F., Qin, D., Plattner, G.-K., Tignor, M., Allen, S. K., Boschung, J., Nauels, A., Xia, Y., Bex, V., and Midgley, P. M., Cambridge University Press, Cambridge, United Kingdom and New York, NY, USA, 2013.

Hawkins, E. and Sutton, R.: The Potential to Narrow Uncertainty in Regional Climate Predictions, B. Am. Meterol. Soc., 90, 10951107, 2009.

Hochstein, A.: Arctic Renewable Energy, a Focal Point for the U.S. Arctic Council Chairmanship. DIPNOTE/US Dept of State Official Blog, 7 May 2015, https://blogs.state.gov/stories/, 2015.

Horstmann, B.: Glacial Lake Outburst Floods in Nepal and Switzerland, New Threats due to Climate Change, Germanwatch, Bonn, http://germanwatch.org/en/2753 (last access: 18 February 2014), 2004.

Hurd, B., Leary, N., Jones, R., and Smith, J.: Relative regional vulnerability of water resources to climate change, J. Am. Water Resour. As., 35, 1399-1409, 1999.

Huss, M., Farinotti, D., Bauder. A., and Funk, M.: Modelling runoff from highly glacierized alpine drainage basins in a changing climate, Hydrol. Process., 22, 3888-3902, 2008.

Ilimi, A.: Estimating Global Climate Change Impacts on Hydropower Projects, The World Bank: Policy Research Working Paper, 4344, 2007.

Inderberg, T. H. and Løchen, L. A.: Adaptation to climate change among electricity distribution companies in Norway and Sweden: lessons from the field, Local Environment, 17, 663-678, doi:10.1080/13549839.2011.646971, 2012.

International Centre for Hydropower (ICH): Risk Management in Hydropower Development Proceedings, 2016.

International Commission on Large Dams (ICOLD): Draft Bulletin: Global Climate Change, Dams, Reservoirs, and Related Water Resources, http://www.icold-cigb.org/ (last access: 3 April 2016), 2013.

International Energy Agency (IEA): Overview of IEA Hydropower Implementation Agreement, http://www.nef.or.jp/ ieahydro/contents/pdf/info/info201303-1-3.pdf (last access: 3 April 2016), 2013.

International Hydropower Association (IEA): IHA Hydropower Report, https://www.hydropower.org/publications (last access: 3 April 2016), 2010.

International Hydropower Association (IEA): IHA Hydropower Report, https://www.hydropower.org/2013-hydropower-report (last access: 3 April 2016), 2013.

Jiménez Cisneros, B. E., Oki, T., Arnell, N. W., Benito, G., Cogley, J. G. Döll, P., Jiang, T., and Mwakalila, S. S.: Freshwater resources, in: Climate Change 2014: Impacts, Adaptation, and Vulnerability. Part A: Global and Sectoral Aspects, Contribution of Working Group II to the Fifth Assessment Report of the Intergovernmental Panel on Climate Change, edited by: Field, C. B., Barros, V. R., Dokken, D. J., Mach, K. J., Mastrandrea, M. D., Bilir, T. E., Chatterjee, M., Ebi, K. L., Estrada, Y. O., Genova, R. C., Girma, B., Kissel, E. S., Levy, A. N., MacCracken, S., Mastrandrea, P. R., and White, L. L., Cambridge University Press, Cambridge, United Kingdom and New York, NY, USA, 229269, 2014.

Jansson, P., Hock, R., and Schneider, T.: The concept of glacier storage: a review, J. Hydrol., 282, 116-129, doi:10.1016/S00221694(03)00258-0, 2003.

Johannesson, T., Aðalgeirsdóttir, G., Ahlstrom, A., Andreassen, L. M., Bjornsson, H., de Woul, M., Elvehoy, H., Flowers, G. E., Guðmundsson, S., Hock, R., Holmlund, P., Palsson, F., Radic, V., Sigurðsson, O., and Thorsteinsson, T.: The impact of climate change on glaciers and glacial runoff in the Nordic countries, European Conference on Impacts of Climate Change on Renewable Energy Sources, Reykjavik, Iceland, 5-9 June, 31-34, 2006.

Jones, J. B. and Rinehart, A. J.: The long-term response of stream flow to climatic warming in headwater streams of interior Alaska, Can. J. Forest Res., 40, 1210-1218, 2010.

Jonsdottir, J. F.: A runoff map based on numerically simulated precipitation and a projection of future runoff in Iceland, Hydrolog. Sci. J., 53, 100-111, 2008.

Jost, G. and Weber, F.: Potential Impacts of Climate Change on BC Hydro's Water Resources, BC: BC Hydro, https://www.bchydro.com/content/dam/hydro/medialib/internet/ documents/about/climate_change_report_2012.pdf (last access: 28 December 2016), 2012.

Kane, D. L., Gieck, R. E., and Hinzman, L. D.: Evapotranspiration from a Small Alaskan Arctic Watershed, Nord. Hydrol., 21, 253272, 1990.

Kaunda, C. S., Kimambo, C. Z., and Nielsen, T. K.: Hydropower in the Context of Sustainable Energy Supply: A Review of Technologies and Challenges, International Scholarly Research Notices, 2012.

Key, J., Goodison, B., Schoner, W., Godoy, O., Ondras, M., and Snorrason, A.: A Global Cryosphere Watch, Arctic, 68, 48-58, 2015.

Kirkinen, J., Martikainen, A., Holttinen, H., Savolainen, I., Auvinen O., and Syri, S.: Impacts on the energy sector and adaptation of the electricity network business under a changing climate in Finland, FINADAPT Working Paper 10, Finnish Environment Institute Mimeographs 340, Helsinki, 36 pp., 2005.

Koutsoyiannis, D., Montanari, A., Lins, H. F., and Cohn, T. A.: Discussion of "The implications of projected climate change for freshwater resources and their management" Climate, hydrology 
and freshwater: towards an interactive incorporation of hydrological experience into climate research, Hydrolog. Sci. J., 54, 394-405, 2009.

Kundzewicz, Z. W. and Stakhiv, E. Z.: Are climate models "ready for prime time" in water resources management applications, or is more research needed?, Hydrolog. Sci. J., 55, 1085-1089, 2010.

Kunreuther, H., Heal, G., Allen, M., Edenhofer, O., Field, C. B., and Yohe, G.: Risk management and climate change, Nature Climate Change, 3, 447-450, 2013.

Kutuzov, S. and Shahgedanova, M.: Glacier retreat and climatic variability in the eastern Terskey-Alatoo, inner Tien Shan between the middle of the 19th century and beginning of the $21 \mathrm{st}$ century, Global Planet. Change, 69, 59-70, 2009.

Lawrence, D. and Hisdal, H.: Hydrological projections for floods in Norway under a future climate, Report 5 Norwegian Water Resources and Energy Directorate, 47 pp., 2011.

Lettenmaier, D. P., Wood, A. W., Palmer, R. N., Wood, E. F., and Stakhiv, E. Z.: Water resources implications of global warming: A US regional perspective, Climatic Change, 43, 537-579, 1999.

Li, H., Wigmosta, M. S., Huang, H. W. M., Ke, Y., Coleman, A. M., and Leung, L. R.: A Physically Based Runoff Routing Model for Land Surface and Earth System Models, J. Hydrometeorol., 14, 808-828, 2013.

Locher, H., Hermansen, G. Y., Johannesson, G. A., Xuezhong, Y., Phiri, I., Harrison, D., Hartmann, J., Simon, M., O'Leary, D., Lowrance, C., Fields, D., Abadie, A., Abdel-Malek, R., Scanlon, A., and Nyman, K.: Initiatives in the hydro sector post-World Commission on Dams - The Hydropower Sustainability Assessment Forum, Water Alternatives, 3, 43-57, 2010.

Lofgren, B. M., Gronewold, A. D., Acciaioli, A., Cherry, J. E., Steiner, A., and Watkins, D.: Methodological Approaches to Projecting the Hydrologic Impacts of Climate Change, Earth Interact., 17, 1-19, doi:10.1175/2013EI000532.1, 2013.

Lowrey, J., Ray, A., and Webb, R.: Factors Influencing the Use of Climate Information by Colorado Municipal Water Managers, Clim. Res., 40, 103-119, 2009.

Lund, J. R.: Integrating social and physical sciences in water management, Water Resour. Res., 51, 5905-5918, doi:10.1002/2015WR017125, 2015.

Madani, K.: Hydropower licensing and climate change: Insights from cooperative game theory, Adv. Water Resour., 34, 174-183, 2011

Madani, K. and Lund, J. R.: Estimated impacts of climate warming on California's high-elevation hydropower, Climatic Change, 102, 521-538, 2010.

Malewitz, J.: Drought Hastens End of a Region's Hydropower Era, The Texas Tribune and the New York Times, http://nyti.ms/ 1cLfBrx (last access: 3 April 2016), 2014.

Markoff, M. S. and Cullen, A. C.: Impact of climate change on Pacific Northwest hydropower, Climatic Change, 87, 451-469, 2008.

Marttila, V., Granholm, H., Laanikari, J., Yrjölä, T., Aalto, A., Heikinheimo, P., Honkatukia, J., Järvinen, H., Liski, J., Merivirta, R., and Paunio, M.: Finland's National Strategy for Adaptation to Climate Change, Ministry of Agriculture and Forestry of Finland Publication, 1a/2005, 2005.

Mastrandrea, M. D., Field, C. B., Stocker, T. F., Edenhofer, O., Ebi, K. L., Frame, D. J., Held, H., Kriegler, E., Mach, K. J.,
Matschoss, P. R., Plattner, G.-K., Yohe, G. W., and Zwiers, F. W. Guidance Note for Lead Authors of the IPCC Fifth Assessment Report on Consistent Treatment of Uncertainties. Intergovernmental Panel on Climate Change (IPCC), https://www.ipcc.ch/ pdf/supporting-material/uncertainty-guidance-note.pdf (last access: 27 December 2016), 2010.

McAfee, S., Guentchev, G., and Eischeid, J.: Reconciling precipitation trends in Alaska: 2. Gridded data analyses, J. Geophys. Res.Atmos., 119, 13820-13837, doi:10.1002/2014JD022461, 2014.

McAfee, S. A., Guentchev, G., and Eischeid, J. K.: Reconciling precipitation trends in Alaska: 1. Station-based analyses, J. Geophys. Res.-Atmos., 118, 7523-7541, 2013.

McClelland, J. W., Tank, S. E., Spencer, R. G. M., and Shiklomanov, A. I.: Coordination and Sustainability of River Observing Activities in the Arctic, Arctic, 68, 59-68, 2015.

Mehta, V. K., Rheinheimer, D. E., Yates, D., Purkey, D. R., Viers, J. H., Young, C. A., and Mount, J. F.: Potential impacts on hydrology and hydropower production under climate warming of the Sierra Nevada, J. Water Clim. Change, 2, 29-43, 2011.

Mekis, É. and Vincent, L. A.: An overview of the second generation adjusted daily precipitation dataset for trend analysis in Canada, Atmos. Ocean, 49, 163-177, 2011.

Melillo, J. M., Richmond, T. C., and Yohe, G. W. (Eds.): Climate Change Impacts in the United States: The Third National Climate Assessment, US Global Change Research Program, 841 pp., doi:10.7930/J0Z31WJ2, 2014.

Miller, C.: Hybrid management: boundary organizations, science policy, and environmental governance in the climate regime, Sci. Technol. Hum. Val., 26, 478-500, 2001.

Milly, P. C. D., Betancourt, J., Falkenmark, M., Hirsch, R. M., Kundzewicz, Z. W., Lettenmaier, D. P., and Stouffer, R. J.: Climate change - Stationarity is dead: Whither water management?, Science, 319, 573-574, 2008.

Minville, M., Brissette, F., Krau, S., and Leconte, R.: Adaptation to Climate Change in the Management of a Canadian WaterResources System Exploited for Hydropower, Water Resour. Manag., 23, 2965-2986, 2009.

Minville, M., Brissette, F., and Leconte, R.: Impacts and Uncertainty of Climate Change on Water Resour. Manag. of the Peribonka River System (Canada), J. Water Res. Pl.-ASCE, 136, 376-385, 2010a.

Minville, M., Krau, S., Brissette, F., and Leconte, R.: Behaviour and Performance of a Water Resource System in Quebec (Canada) Under Adapted Operating Policies in a Climate Change Context, Water Resour. Manag., 24, 1333-1352, 2010b.

Molarius, R., Keranen, J., Schabel, J., and Wessberg, N.: Creating a climate change risk assessment procedure: Hydropower plant case, Finland, Hydrol. Res., 41, 282-294, 2010.

Moran, E. H. and Solin, G. L.: Preliminary water-table map and water-quality data for part of the Matanuska-Susitna Valley, Alaska, 2005, US Geological Survey Open-File Report 20061209, 43 pp., 2006.

Mote, P. W.: Climate-Driven Variability and Trends in Mountain Snowpack in Western North America, J. Climate, 19, 62096220, 2006.

Mukheibir, P.: Potential consequences of projected climate change impacts on hydroelectricity generation, Climatic Change, 121, 67-78, 2013 
Murray, M. S., Anderson, L., Cherkashov, G., Cuyler, C., Forbes, B., Gascard, J. C., Haas, C., Schlosser, P., Shaver, G., Shimada, K., Tjernström, M., Walsh, J., Wandell, J., and Zhao, Z.: International Study of Arctic Change: Science Plan., ISAC International Program Office, Stockholm, 2010.

Narama, C., Duishonakunov, M., Kääb, A., Daiyrov, M., and Abdrakhmatov, K.: The 24 July 2008 outburst flood at the western Zyndan glacier lake and recent regional changes in glacier lakes of the Teskey Ala-Too range, Tien Shan, Kyrgyzstan, Nat. Hazards Earth Syst. Sci., 10, 647-659, doi:10.5194/nhess-10-6472010, 2010.

NOAA/NMFS: Study request to the Federal Energy Regulatory Commission, Susitna-Watana Project, Alaska (P-14241), Enclosure 12, Susitna River Project Effects Under Changing Climate Conditions Study Request, 31 May 2012, https://alaskafisheries. noaa.gov/sites/default/files/fercsusitnamasterstudy.pdf (last access: 27 December 2016), 2012.

NOAA/NMFS: Study modification request to the Federal Energy Regulatory Commission, Susitna-Watana Project, Alaska (P-14241), 7.7 Glacial and Runoff Changes, https://alaskafisheries.noaa.gov/sites/default/files/ fercsusitnafinalreviewdocument062216.pdf, 37 pp., 27 December 2016.

Oki, T. and Kanae, S.: Global hydrological cycles and world water resources, Science, 313, 1068-1072, 2006.

Olchev, A. and Novenko, E.: Estimation of potential and actual evaportranspiration of boreal forest ecosystems in the European part of Russia during the Holocene, Environ. Res. Lett., 6, 045213, doi:10.1088/1748-9326/6/4/045213, 2011.

O’Neel, S., Hood, E., Arendt, A., and Sass, L.: Assessing stream flow sensitivity to variations in glacier mass balance, Climatic Change, 123, 329-341, doi:10.1007/s10584-013-1042-7, 2014.

Ouranos: The Impact of Climate Change on Hydro-Electricity Generation, CEATI REPORT No. T072700-0409, www.ceati.com (last access: 3 April 2016), 2008.

Patel, G. P. and Singhal, S.: Perception and management of risk in hydropower projects, in Proceedings of the International Conference on Hydropower for Sustainable Development, 5-7 February 2015, Dehradun, India, 331-338, 2015.

Payne, J. T., Wood, A. W., Hamlet, A. F., Palmer, R. N., and Lettenmaier, D. P.: Mitigating the effects of climate change on the water resources of the Columbia River Basin, Climatic Change, 62, 233-256, 2004.

Peacock, S.: Projected Twenty-First-Century Changes in Temperature, Precipitation, and Snow Cover over North America in CCSM4, J. Climate, 25, 4405-4428, doi:10.1175/JCLI-D-1100214.1, 2012.

Pechlivanidis, I. G., Jackson, B. M., and McIntyre, N. R.: Catchment scale hydrological modelling: a review of model types, calibration approaches and uncertainty analysis methods in the context of recent developments in technology and Applications, Global NEST J., 13, 193-214, 2011.

Perez-Diaz, J. I. and Wilhelmi, J. R.: Assessment of the economic impact of environmental constraints on short-term hydropower plant operation, Energ. Policy., 38, 7960-7970, 2010.

Pittock, J.: Viewpoint - Better Management of Hydropower in an Era of Climate Change, Water Alternatives, 3, 444-452, 2010.

Prowse, T., Alfredsen, K., Beltaos, S., Bonsal, B., Bowden, W. B., Duguay, C., Korhola, A., McNamara, J., Vincent, W. F., Vuglin- sky, V., Walter Anthony, K. M., and Weyhenmeyer, G. A.: Effects of changes in Arctic river and lake ice, Ambio, 40, 63-74, doi:10.1007/s13280-011-0217-6, 2011.

Prowse, T. D. and Beltaos, S.: Climatic control of riverice hydrology: a review, Hydrol. Process., 16, 805-822, doi:10.1002/hyp.369, 2002.

Quinton, W. L., Hayashi, M., and Chasmer, L. E.: Permafrost-thawinduced land-cover change in the Canadian subarctic: implications for water resources, Hydrol. Process, 25, 152-158, 2011.

Radić, V. and Hock, R.: Glaciers in the Earth's Hydrological Cycle: Assessments of Glacier Mass and Runoff Changes on Global and Regional Scales, Surv. Geophys., 35, 813-837, 2014.

Rajagopalan, B., Nowak, N., Prairie, J., Hoerling, M., Harding, B., Barsugli, J., Ray, A., and Udall, B.: Water supply risk on the Colorado River: Can management mitigate?, Water Resour. Res., 45, W08201, doi:10.1029/2008WR007652, 2009.

Raje, D. and Mujumdar, P. P.: Reservoir performance under uncertainty in hydrologic impacts of climate change, Adv. Water Resour., 33, 312-326, 2010.

Rawlins, M. A., Steele, M., Holland, M., Adam, J. C., Cherry, J. E., Francis, J. A., Groisman, P., Hinzman, L. D., Huntington, T. G., Kane, D. L., Kimball, J. S., Kwok, R., Lammers, R. B., Lettenmaier, D. P., McDonald, K. C., Podest, E., Pundsack, J. W., Rudels, B., Serreze, M. C., Shiklomanov, A., Skagseth, O., Troy, T. J., Vorosmarty, C. J., Wensnahan, M., Wood, E. R., Woodgate, R., Yang, D., Zhang, K., and Zhang, T.: Analysis of the Arctic System Freshwater Cycle Intensification: Observations and Expectations, J. Climate, 23, 5715-5737, 2010.

Ray, P. A. and Brown, C. M.: Confronting climate uncertainty in water resources planning and project design: the decision tree framework, Washington, D.C., World Bank Group, 149 pp., 2015.

Rayner, S., Lach D., and Ingram, H.: Weather forecasts are for wimps: Why water resource managers do not use climate forecasts, Climatic Change, 69, 197-227, 2005.

REAP/Renewable Energy Alaska Projects: http:// alaskarenewableenergy.org/index.php/clean-energy-in-alaska/ map-of-re-installations/, last access: 27 December 2016.

Rheinheimer, D. E., Yarnell, S. M., and Viers, J. H.: Hydropower Costs of Environmental Flows and Climate Warming in California's Upper Yuba River Watershed, River Res. Appl., 29, 12911305, 2013.

Rhines, A., and Huybers, P.: Frequent summer temperature extremes reflect changes in the mean, not the variance, P. Natl. Acad. Sci. USA, 110, E546, doi:10.1073/pnas.1218748110, 2013.

Richardson, S. D. and Reynolds, J. M.: An overview of glacial hazards in the Himalayas, Quatern. Int., 65, 31-47, 2000.

Robinson, P. J.: Climate change and hydropower generation, Int. J. Climatol., 17, 983-996, 1997.

Rummukainen, M., Raisanen, J., Bjorge, D., Christensen, J. H., Christensen, O. B., Iversen, T., Jylha, K., Olafsson, H., and Tuomenvirta, H.: Regional climate scenarios for use in Nordic water resources studies, Nord. Hydrol., 34, 399-412, 2003.

Schaefli, B., Hingray, B., and Musy, A.: Climate change and hydropower production in the Swiss Alps: quantification of potential impacts and related modelling uncertainties, Hydrol. Earth Syst. Sci., 11, 1191-1205, doi:10.5194/hess-11-11912007, 2007. 
Scherer, L. and Pfister S: Hydropower's Biogenic Carbon Footprint, PLoS ONE, 11, e0161947, doi:10.1371/journal.pone.0161947, 2016.

Serreze, M. C. and Barry, R. G.: The Arctic Climate System, 2nd Edn., Cambridge University Press, Cambridge, 415 pp., 2014.

Shrestha, R. R., Schnorbus, M. A., Werner, A. T., and Berland, A. J.: Modelling spatial and temporal variability of hydrologic impacts of climate change in the Fraser River basin, British Columbia, Canada, Hydrol. Process., 26, 1840-1860, 2012.

Sorg, A., Bolch, T., Stoffel, M., Solomina, O., and Beniston, M.: Climate change impacts on glaciers and runoff in Tien Shan (Central Asia), Nature Climate Change, 2, 725-731, 2012.

Timalsina, N. P., Charmasson, J., and Alfredsen, K. T.: Simulation of the ice regime in a norwegian regulated river, Cold Reg. Sci. Technol., 94, 61-73, 2013.

Toniolo, H. and Schultz, J.: Experiments on sediment trap efficiency in reservoirs, Lakes \& Reservoirs: Research and Management, $10,13-24,2005$.

Vano, J. A., Scott, M. J., Voisin, N., Stöckle, C. O., Hamlet, A. F., Mickelson, K. E. B., Elsner, M. M. G., and Lettenmaier, D. P.: Climate change impacts on water management and irrigated agriculture in the Yakima River Basin, Washington, USA, Climatic Change, 102, 287-317, doi:10.1007/s10584-010-9856-z, 2010.

Veijalainen, N., Lotsari, E., Alho, P., Vehvilainen, B., and Kayhko, J.: National scale assessment of climate change impacts on flooding in Finland, J. Hydrol., 391, 333-350, 2010.

Vicuna, S., Leonardson, R., Hanemann, M. W., Dale, L. L., and Dracup, J. A.: Climate change impacts on high elevation hydropower generation in California's Sierra Nevada: a case study in the Upper American River, Climatic Change, 87, S123-S137, 2008.

Vicuna, S., Dracup, J. A., and Dale, L.: Climate change impacts on two high-elevation hydropower systems in California, Climatic Change, 109, 151-169, 2011.

Viers, J. H.: Hydropower Relicensing and Climate Change, J. Am. Water Resour. As., 47, 655-661, 2011.

Viviroli, D., Archer, D. R., Buytaert, W., Fowler, H. J., Greenwood, G. B., Hamlet, A. F., Huang, Y., Koboltschnig, G., Litaor, M. I., López-Moreno, J. I., Lorentz, S., Schädler, B., Schreier, H., Schwaiger, K., Vuille, M., and Woods, R.: Climate change and mountain water resources: overview and recommendations for research, management and policy, Hydrol. Earth Syst. Sci., 15, 471-504, doi:10.5194/hess-15-471-2011, 2011.
Walsh, J., Wuebbles, D., Hayhoe, K., Kossin, J., Kunkel, K. Stephens, G., Thorne, P., Vose, R., Wehner, M., Willis, J., Anderson, D., Doney, S., Feely, R., Hennon, P., Kharin, V., Knutson, T., Landerer, F., Lenton, T., Kennedy, J., and Somerville, R.: Ch. 2: Our Changing Climate. Climate Change Impacts in the United States: The Third National Climate Assessment, edited by: Melillo, J. M., Richmond, T. C., and Yohe, G. W., US Global Change Research Program, 19-67, doi:10.7930/J0KW5CXT, 2014.

Wada, T., Chikita, K. A., Kim, Y., and Kudo, I.: Glacial Effects on Discharge and Sediment Load in the Subarctic Tanana River Basin, Alaska, Arct. Antarct. Alp. Res., 43, 632-648, 2011.

Wilby, R. L.: Evaluating climate model outputs for hydrological applications, Hydrolog. Sci. J., 55, 1090-1093, 2010.

Wilby, R. L. and Dessai, S.: Robust adaptation to climate change, Weather, 65, 180-185, doi:10.1002/wea.543, 2010.

Wilson, D., Hisdal, H., and Lawrence, D.: Has streamflow changed in the Nordic countries? - Recent trends and comparisons to hydrological projections, J. Hydrol., 394, 334-346, 2010.

World Bank: Directions in hydropower, Washington, DC: World Bank, http://documents.worldbank.org/curated/en/2009/ 03/12331040/directions-hydropower (last access: 3 April 2016), 2009.

World Commission on Dams (WCOD): Dams and Development: A new framework for Decision-Making, www.unep.org/dams/ WCD/report/WCD_DAMSreport.pdf (last access: 27 December 2016, 356 pp., 2000.

Wolken, G., Bliss, A., Hock, R., Whorton, E., Braun, J., Liljedahl, A., Zhang, J., Youcha, E., Schulla, J., Gusmeroli, A., AubryWake, C., Beedlow, A. C., and Hoffman, A.: Susitna-Watana Hydroelectric Project (FERC No. 14241) Glacier and Runoff Changes Study, Final Study Report, 2015.

Yuan, X., Roundy, J. K., Wood, E. F., and Sheffield, J.: Seasonal forecasting of global hydrologic extremes: system development and evaluation over GEWEX basins, B. Am. Meteorol. Soc., 96, 1895-1912, doi:10.1175/BAMS-D-14-00003.1, 2015.

Zeng, H., Jia, G., and Epstein, H.: Recent changes in phenology over the northern high latitudes detected from multisatellite data, Environ. Res. Lett., 6, 045508, doi:10.1088/1748 9326/6/4/045508, 2011. 